\title{
TOXIC EFFECTS OF PHENOTHIAZINES \\ ON THE EYE
}

\section{PROEFSCHRIFT}

TER VERKRIJGING VAN DE GRAAD VAN DOCTOR IN DE GENEESKUNDE AAN DE MEDISCHE FACULTEIT TE ROTTERDAM, OP GEZAG VAN DE

DECAAN PROF, D. C. DEN HAAN, HOOGLERAAR IN DE FACULTEIT DER GENEESKUNDE, TEGEN DE BEDENKINGEN VAN DE FACULTEIT DER GENEESKUNDE TE VERDEDIGEN OP 12 FEBRUARI 1970 TE 16.00 UUR,

DOOR

DIRK JOHANNES BOET geboren in 1920 

Promotor: PROF. DR. H. E. HENKES

Co-referenten: PROF. DR. I. L. BONTA PROF. DR. G. A. LADEE 
Aan mijn vrouw 


\section{CONTENTS}

Introduction

The phenothiazines

Page

Structure

Action

Side effects and toxic reactions

Structural formulas

Survey of toxic effects of drugs on the retina

Toxic effects of arsenic

Toxic effects of quinine and its derivatives

Toxic effects of iodine compounds

Retinotoxic effects of phenothiazines

N.P. 207

Thioridazine

Chlorpromazine

Other oculo-toxic effects of phenothiazine derivatives

Animal experiments

Present study

Material

Method

Observations

Skin and eyelids

Conjuctiva

Cornea.

Lens

Retina

$\begin{array}{ll}\text { Electro-oculogram } & 34\end{array}$

Results

Skin pigmentation

Photosensitivity of the skin

Cornea

Lens

Intra-ocular pressure

Retina

Visual acuity

Colour vision

Electro-oculogram 
$\begin{array}{lr}\text { Discussion } & 49\end{array}$

Skin pigmentations $\quad 50$

Cornea and lens 51

Intra-ocular pressure $\quad 52$

Retinopathy $\quad 52$

Visual acuity $\quad 54$

Colour defects $\quad 54$

Electro-oculogram $\quad 55$

Fluorescein angiography $\quad 56$

Differential diagnosis $\quad 56$

Therapy $\quad 57$

Conclusions $\quad 58$

Summary $\quad 59$

Résumé $\quad 60$

Zusammenfassung $\quad 61$

Samenvatting $\quad 61$

Bibliography 


\section{ACKNOWLEDGEMENTS}

This thesis is a report on a research project set up by the Netherlands General Association for Prevention of Blindness. The secretary of the Association particularly, my colleague Mrs. J. Schappert-Kimmijser, gave me much help and encouragement.

Financial help was provided by the Organization for Health Research T.N.O. and valuable advice was given by Dr. F. A. Nelemans.

This study was performed in the psychiatric hospitals Delta Ziekenhuis, Portugaal - Rotterdam (head: Dr. F. J. Tolsma) and Stichting Rosenburg, The Hague (head: J. Bijl). The medical and nursing staffs of these hospitals lent us every possible assistance.

My colleagues Miss D. A. E. Mertens, Dr. P. P. H. Alkemade, A. Craandijk and J. A. Rozemeyer performed a large part of the practical work necessary for this study.

The electro-oculograms were made by the Electrophysiological Department of the Rotterdam Eye Hospital. Dr. G. H. M. van Lith assisted in the interpretation of the results.

The statistical analysis was performed by G. G. van der Meulen, with the assistance of Miss C. A. van Eck, of the Statistical Bureau ABW-TNO (head: Dr. E. F. Drion). Further help was provided by J. Eling Vos.

Figures were drawn and photographs were made by the Photographic Department of the Rotterdam Eye Hospital and by Dr. C. H. O. M. von Winning.

My wife translated the text and assisted in many other ways. Mrs. V. von Ziegenweidt-Mann typed the manuscript.

To all these people and many others, and especially to Prof. Dr. H. E. Henkes, who has played such an important part in my training as ophthalmologist and in the preparation of this thesis, I offer my sincere thanks. 
The range of usefulness of these preparations increased greatly after the discovery of new derivatives: promethazine in 1930 and chlorpromazine in 1950. LABORIT's work (1952) on the potentiation of anaesthetics by phenothiazines and their hibernating action was largely responsible for the growing interest in these drugs. Other new preparations followed rapidly, so that there are at present about thirty in use and the number is steadily increasing.

\section{Structure}

Phenothiazine has a three-ringed structure in which two benzene rings are linked by a sulphur and a nitrogen atom. The positions 2 and 10 are usually substituted. As the structural formula becomes more asymmetrical the drug becomes more potent. Substitution of a $\mathrm{CF}_{3}$ group in position 2 increases the antipsychotic action.

The phenothiazines can be divided into three groups on the basis of the substitution in position 10, the $\mathrm{N}$ atom (see Scheme, p. 4). The derivatives are:

a. with aliphatic side chain; these are the least potent in their antipsychotic action;

b. with piperidine in the side chain; these are more potent than group a in their antipsychotic action:

c. with piperazine in the side chain; these are the most potent in their antipsychotic action.

\section{Action}

All phenothiazine derivatives have a sedative action. They do not only influence the central nervous system, like the barbiturates and other sedatives, but also affect other organs. These effects have been studied most extensively for chlorpromazine. This preparation has no effect on the motor cortex but depresses the sensory cortex. The action of the thalamus is stimulated and the hypothalamus is depressed. The activity of the extra-pyramidal system is increased by chlorpromazine, to a lesser extent this is also true for N. P. 207 and thioridazine.

The action of chlorpromazine upon the brain stem reticular system appears to be complex. It only slightly raises the threshold of arousal produced by direct electrical stimulation of the brain stem. Judging by changes in the EEG, chlor- 
promazine very effectively blocks arousal produced by auditory and other types of peripheral stimulation (BRADLEY, 1963).

This preparation has strong adrenergic and weaker peripheral cholinergic blocking activity. It decreases the excretion in the urine of gonadotropins, progesterone and oestrogens: it blocks ovulation, suppresses the oestrous cycle and causes infertility and pseudo-pregnancy. The drug has a diuretic action.

The phenothiazines are readily absorbed both parenterally and from the digestive tract. Sixty to seventy per cent is removed from the portal circulation by the liver. Excretion by the kidney is very slow. In some cases various metabolites and even free chlorpromazine could be found in the urine 6-12 months after the administration of the drug had been stopped. The excretion in the faeces of prochlorpromazine and triffuoperazine is much higher than that of chlorpromazine, the reason for this is probably the nature of the side chains. (GOODMAN \& GILMAN, 1967: HAASE \& JANSSEN, 1965).

PERRY, CULLING, BERRY \& HANSEN give the following account of the metabolism of chlorpromazine: "Chlorpromazine is metabolized in man to form a wide variety of derivatives. The $\mathrm{N}$-dimethylaminopropyl side chain can be either partially or completely demethylated, or converted to the $\mathrm{N}$-oxide, and the phenothiazine nucleus is subject to sulfoxidation and to ring hydroxylation. The hydroxylated or phenolic derivatives can in turn be conjugated with glucuronic or sulfuric acid. Since these alterations can occur singly or in combination, a large number of metabolites is possible theoretically and some of these may not only account for the pharmacological activity of chlorpromazine but also for its varied toxic effects."

After absorption the phenothiazines spread rapidly to all parts of the body. They can be demonstrated, in order of decreasing concentration, in the lungs, liver, adrenal glands, spleen, brain ard blood.

POTrs in 1962, by means of experiments on rabbits, rats and hamsters, discovered that the concentration of phenothiazine in the uveal tract is fifty times that in any other organ. The concentration in the choroid was the highest, followed by the ciliary body and the iris. Albino rats did not exhibit the uvealconcentration-phenomenon. In experiments in vitro with a phenothiazine derivative and a suspension of pigment granules from the uveal tract, the granules were found to absorb the phenothiazine derivative. Porrs concludes from this that the pigment granules are the place where the phenothiazines are stored in vivo.

CASSANO et al. (1968) also demonstrated uveal concentration in cats. 


\section{Side effects and toxic reactions}

The side effects which may be produced by chlorpromazine are palpitations, faintness, nasal stuffiness, a dry mouth and slight constipation. These effects are not difficult to treat. On the other hand, the orthostatic hypotension which may occur after the administration of phenothiazines is sometimes very difficult to combat. Pharmacological over-activity may result in parkinsonism, dyskinesia and akathisia (AXD, 1961, 1963).

Other toxic reactions of the phenothiazines include: ocular complications. leucocytosis, leucopenia, eosinophilia (HARTINETT, 1955; BACON, 1964), jaundice and skin reactions (HOLLYSTER, 1964, 1965; IPPEN, 1962; JUNG et al., 1963).

Before paying further attention to the ocular complications (see P. 17) a survey of the phenothiazine derivatives in present use. together with their structural formulas and trade names, is given.

For historical interest the structural formulas of phenothiazine itself, methylene blue and N. P. 207 are included, although they are no longer used therapeutically.

\section{Structural formulas}<smiles>c1ccc2c(c1)Nc1ccccc1S2</smiles>
phenothiazine<smiles>CN(C)c1ccc2c(c1)Nc1ccccc1[SH]2Cl</smiles>
methylene blue<smiles>CN1CCCCC1CCN1c2ccccc2Sc2ccc(Cl)cc21</smiles> 
a. phenothiazines with aliphatic side chain

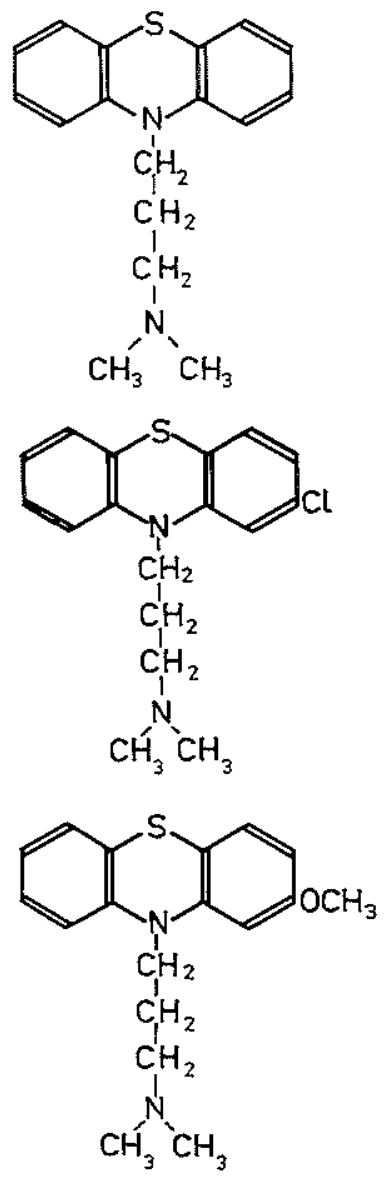

promazine

10-(3-dimethylaminopropyl)-phenothiazine Prazine, Sparine. Protactyl, Verophen.

chlorpromazine

2-chlor-10-(3-dimethylaminopropyl)phenothiazine

Largactil, 4560 RP, Megaphen, Thorazine, Hibernal

methopromazine (methoxypromazine)

2-methoxy-10-(3-dimethylaminopropyl)phenothiazine

Mopazine, Tentone

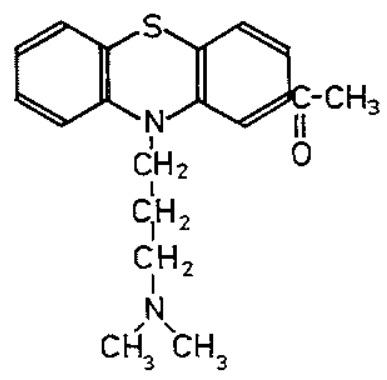

acepromazine

2-acetyl-10-(3-dimethylaminopropyl)phenothiazine

Plegicil, Notensil, Soprintin 
<smiles>CN(C)CCCN1c2ccccc2Sc2ccccc21</smiles><smiles>CN(C)CC(CN1c2ccccc2Sc2ccccc21)N(C)C</smiles><smiles>CC(CN(C)C)CN1Cc2ccccc2Sc2ccccc21</smiles><smiles>COc1cc2c(cc1C)N(CC(C)CN(C)C)c1ccccc1S2</smiles>

triflupromazine

2-trifluoromethyl-10-(3-dimethylaminopropyl)-phenothiazine

Siquil, Psyquil, Vesprin, Vespral.

SKF 4648

aminopromazine

10-(2,3-bis-(dimethylamino)-propyl)phenothiazine

Lorusil, Lispamol trimeprazine (alimémazine)

10-(3-dimethylamino-2-methyl-propyl)phenothiazine

Nedeltran. Temaril, Théralène, Panectyl, Repeltin, Vallergan laevomepromazine (methotrimeprazine) 2-methoxy-10-(3-dimethylamino-2-methylpropyl)-phenothiazine

Nozinan. 7044 RP. Neurocil, Veractil 
<smiles>CC(CN1c2ccccc2Sc2ccccc21)N(C)C</smiles>

promethazine

10-(2-dimethylaminopropyl)-phenothiazine Phenergan, 3277 RP, Atosil<smiles>CCC(=O)c1cc2c(cc1CC)N(CC(C)N(C)C)c1ccccc1S2</smiles>

propiomazine

2-propionyl-10-(2-dimethylaminopropyl)phenothiazine

Largon. Wy-1359, Dorevane

b. phenothiazines with a piperidine derivative in the side chain<smiles>CN1CCCC(CN2c3ccccc3Sc3ccccc32)C1</smiles>

mepazine (pecazine)

10-(N-methyl-3-piperidylmethyl)phenothiazine

Pacatal, Lacumin<smiles>CSc1cc2c(cc1SC)N(CCC1CCCCN1C)c1ccccc1S2</smiles>

thioridazine

2-methylmercapto-10-(N-methyl-2piperidylethyl)-phenothiazine

Melleril, Mellaril 


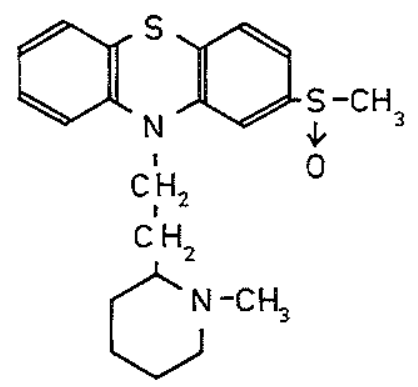

\section{mesoridazine}

2-methylsulphinyl-10-(N-methyl-2piperidylethyl)-phenothiazine

Serentil, TPS-23

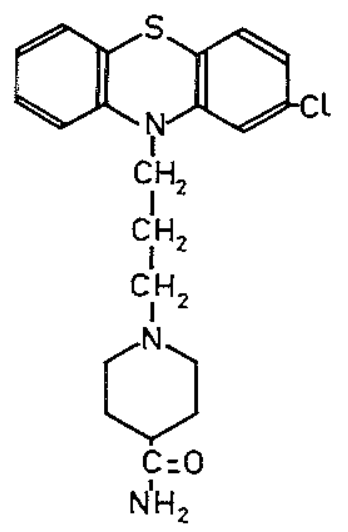

\section{pipamazine}

2-chlor-10-(3-(4-carbamoyl-piperidyl)propyl)-phenothiazine

Mornidine

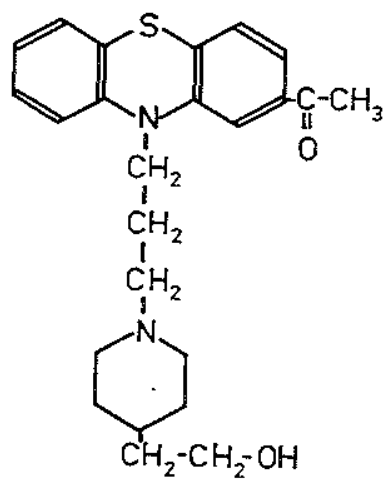

piperacetazine

2-acetyl-10-(3-(4-(ß-hydroxyethyl)piperidine)-propyl)-phenothiazine Quide. 


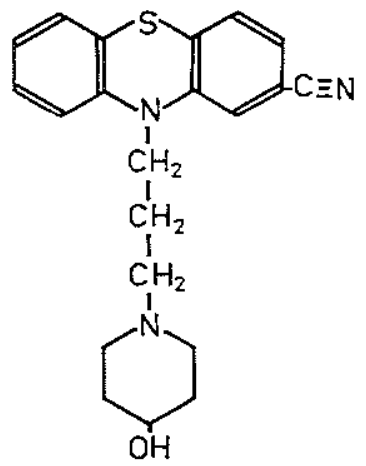

propericiazine

2-cyano-10-(3-(4- hydroxypiperidino)propyl)-phenothiazine

Neuleptil, 8909 RP, Aolept

c. phenothiazines with a piperazine (or piperazinyl) group in the side chain<smiles>CN1CCN(CCCN2c3ccccc3Sc3ccccc32)CC1</smiles>

perazine

10-(3-(1-methyl-4-piperazinyl)- propyl)phenothiazine

Taxilan<smiles>CN1CCN(CCCN2c3ccccc3Sc3ccccc32)CC1</smiles>

prochlorperazine (prochlorpémazine) 2-chlor-10-(3-(1-methyl-4-piperazinyl)propyl)-phenothiazine

Stemetil, 6140 RP, Témentil, Nipodal, Compazine 
<smiles>CN1CCN(CCCN2c3ccccc3Sc3ccc(C(F)(F)F)cc32)CC1</smiles>

trifluoperazine

2-trifluoromethyl-10-(3-(1-methyl-4piperazinyl)-propyl)-phenothiazine

Terfluzine, Stelazine, Jatroneural<smiles>CCSc1ccc2c(c1)N(CCCN1CCN(C)CC1)c1ccccc1S2</smiles>

thiethylperazine

2-ethylmercapto-10-(3-(1-methyl-4piperazinyl)-propyl)-phenothiazine Torecan

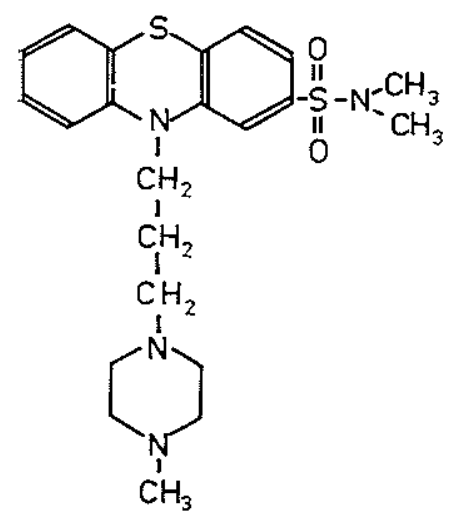

thioproperazine

2-dimethylsulphamoyl-10-(3-(1-methyl-4piperazinyl)-propyl)-phenothiazine Majeptil, 7843 RP, Vontil 


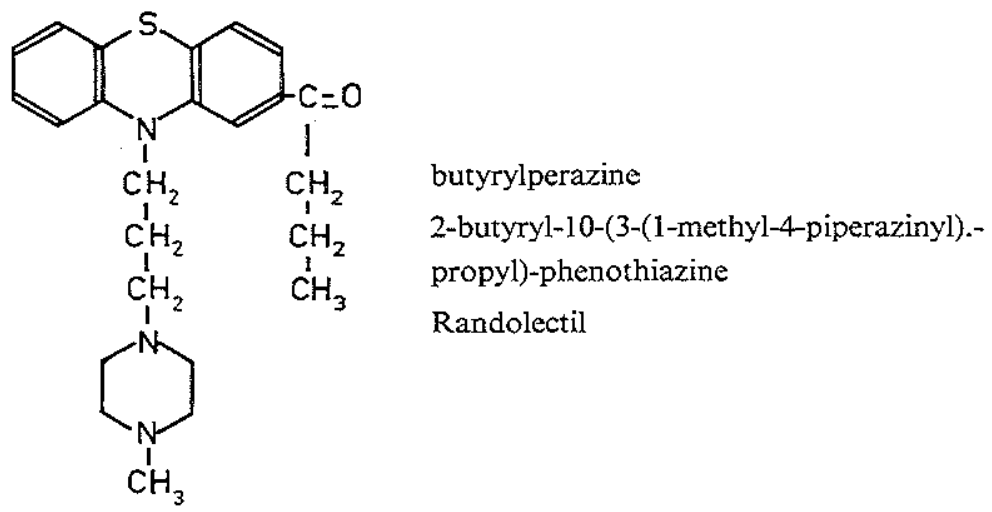<smiles>OCCN1CCN(CCCN2c3ccccc3Sc3ccccc32)CC1</smiles>

perphenazine

2-chlor-10-(3-(1-hydroxyethyl-4piperazinyl)-propyl)-phenothiazine

Trilafon, Decentan, Fentazin<smiles>OCCN1CCN(CCCN2c3ccccc3Sc3ccccc32)CC1</smiles>

fluphenazine

2-trifluoromethyl-10-(3-(1-hydroxyethyl4-piperazinyl)-propyl)-phenothiazine

Sevinol, Permitil, Omca. Prolixin. Moditen 
<smiles>CCN1CCN(CCO)CC1</smiles>

acetophenazine 2-acetyl-10-(3-(1-hydroxyethyl-4piperazinyl)-propyl)-phenothiazine Tindal<smiles>CCCCN1c2ccccc2Sc2ccc(C(=O)CC)cc21</smiles>

carphenazine 2-propionyl-10-(3-(1-hydroxyethyl-4piperazinyl)-propyl)-phenothazine Prokethazine, $\mathrm{W}_{\mathrm{y}-2445}$<smiles>CC(=O)OCN1CCN(CCn2c3ccccc3sc3ccccc3n2CCc2ccccc2)CC1</smiles>

thiopropazate

2-chlor-10-(3-(1-acetoxyethyl-4- piperazinyl)-propyl)-phenothiazine

Dartal, Dartilan, Dartalan 


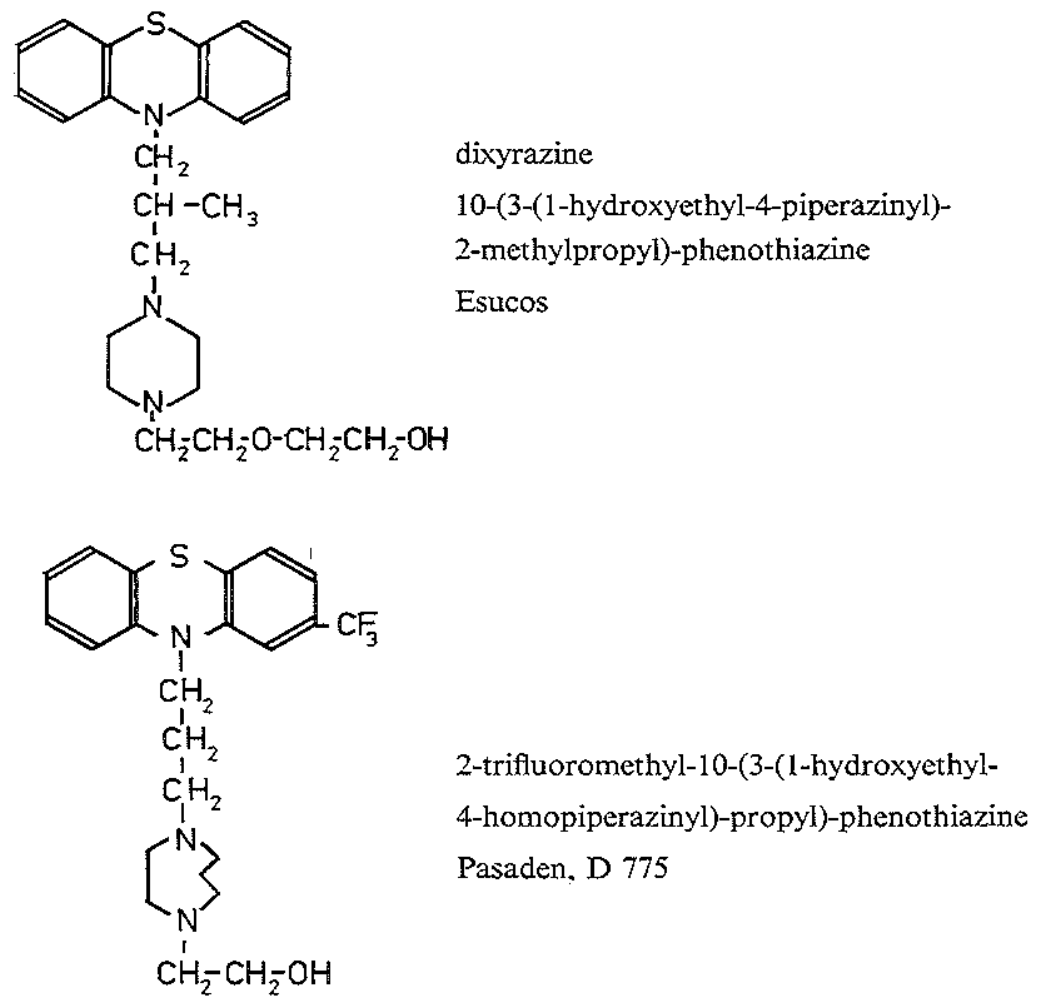

SURVEY OF TOXIC EFFECTS OF DRUGS ON THE RETINA

Damage to the eye caused by the administration of drugs has been recognized for a long time. At the end of the last century and the beginning of this, most attention was being paid to arsenic.

\section{Toxic effects of arsenic}

In 1907 ROBERT KOCH described 22 cases of blindness among 900 patients who had been treated with Atoxyl (a compound of arsenic) for sleeping sickness. Reduction of the visual field and anomalies in blue-yellow vision were also observed. In some cases atrophy of the optic nerve was found. 
Pathological examination, performed by IGERSHEIMER in 1908 and 1909 and by BIRCH-HIRSCHFELD and KÖSTER in 1910 (quoted by JESS, 1921), revealed degeneration of the medullary sheaths of the optic nerve and of the ganglion cells and the nerve fibre layer of the retina. The nuclei of the rods also showed degenerative changes but the nuclei of the cones were apparently unaffected by the arsenic.

Other compounds of arsenic, such as arsacetin, spirasyl. soamin, orsodan and indarsol, may cause similar damage to the retina and optic nerve. Salvarsan, however, is not known to have caused serious damage to the eye.

\section{Toxic effects of quinine and its derivatives}

At about the same time optochine (ethyl hydrocupeine), a quinine alkaloid. began to be used in cases of pneumo-, strepto- and staphylococcal infection.

Blindness caused by this drug has been described. The pupils do not react to light and react poorly to convergence. The retinal arteries are narrow and the veins are wide. There is oedema of the retina round the disc and the macula lutea. Sometimes the periphery of the retina is patchily pigmented. In the course of time optic atrophy develops.

Pathological examination shows that the nerve fibre layer of the retina has become thinner on the nasal side of the disc. The ganglion cells are degenerated throughout the retina. The walls of the small blood vessels. especially the adventitia, are thickened. The choroid is atrophied on the nasal side; degeneration of the pigment epithelium and migration of pigment are seen. The optic nerve is atrophic.

Both clinically and pathologically this picture resembles that of quinine intoxication. Here also marked loss of vision and oedema of the retina are found in the acute stage. The pupils are wide and do not react to light and only poorly to convergence. The voltage of the various components of the ERG and the standing potential - measured by way of the EOG - are Iow. Optic atrophy and narrowing of the blood vessels do not occur until later. Years after the acute onset the ERG and EOG are still clearly subnormal and the visual field is still markedly restricted: the visual acuity, however, usually returns to normal. It is now thought that quinine and its derivatives have a direct toxic action on the ganglion cells of the retina: formerly the vasoconstriction was thought to be the primary cause of the quinine amblyopia.

Eucupine (iso-amyl hydrocupreine), another quinine alkaloid used in streptoand staphylococcal infections, can also cause similar lesions. 
Optochine, quinine and eucupine have a quinoline nucleus in common:

$$
\mathrm{C}_{9} \mathrm{H}_{7} \mathrm{~N}:
$$<smiles>C1CCC2NCCCC2C1</smiles>

In 1921 JESS experimented with quinoline on rabbits which developed a retinopathy. The fundus had a speckled appearance, with white areas and dark patches due to migration of pigment. The optic disc was pale and the arteries were extremely narrow. There were crystals on the retina. Histologically depigmentation of the pigment epithelium was seen, with migration of the pigment out of the epithelium, circumscribed areas of oedema in and between the nuclear layers of the retina and areas in which the rods and cones had disappeared. The nerve fibre layer and the ganglion cell layer were atrophic, as also was the optic nerve. In addition, a transitory cataract was seen in the lens.

Irreversible cataract can be produced in rabbits by the injection of naphthalene. The structural formula of this substance is very similar to that of quinoline. only the $\mathrm{N}$ atom is replaced by a $\mathrm{CH}$ group:<smiles></smiles>

The fundus picture and the histological changes in the retina resemble closely those produced by quinoline.

A quinoline group is also found in plasmochine, quinacrine, chloroquine, amodiaquine and hydroxychloroquine. Chloroquine and hydroxychloroquine especially are extensively used in the treatment of lupus erythematodes and rheumatism.

Retinopathy resulting from chloroquine therapy was described in a publication by HOBBS, SORSBX \& FREEDMAN in 1959. The signs and symptoms are loss of vision, temporal reduction of the visual field with paracentral scotomata, pale optic discs. narrowing of the retinal blood vessels, migration of pigment in the periphery of the fundus, and a ring of pigment round the fovea (bull's eye). BUTLER (1966) pointed out that the first visible pigmentary disturbance appears more frequently in the periphery than at the macula. 
A lowered EOG is found in the cases with severe retinopathy. As the lower limit of normal BUTLER took a value of $185 \%$ for the rise in resting potential in light adaptation as percentage of the lowest value in dark adaptation (LP/DT ratio); it would appear subsequently, however, that this value is probably too high.

Other ocular lesions caused by chloroquine are accommodative palsy and keratopathy. The accommodative palsy is usually transitory and occurs at the beginning of the treatment. The keratopathy often causes deterioration of vision. It affects the epithelium and is probably caused by chemical substances which are dissolved in the tears and become deposited on the cornea. Complete recovery of the corneal epithelium always takes place if the administration of the drug is stopped: the retinal condition. however, is irreversible.

\section{Toxic effects of iodine compounds}

In 1926 SCEEERER described a case of puerperal sepsis in which acute severe loss of vision occurred after the intravenous injection of $100 \mathrm{cc}$. Septojod (a $10 \times$ concentration of Pregl's solution). At first there was oedema of the retina. especially in the centre; later there was marked migration of pigment throughout the retina; the blood vessels were unaffected.

The pigment was described by SCKEERER and by VON BÜNAU (1929) as resembling coffee grounds. ROGGENKÄMPER (1927) compared the fundus picture with that of retinitis pigmentosa and applied the treatment for that condition which was usual at that time: he gave an intravenous injection of a $10 \%$ lecithin solution and obtained a marked improvement of vision. SALLMANN (1933) and OHM (1934) and VON BÜNAU, however, also observed spontaneous improvement of this retinopathy. Disturbances of dark adaptation were not found.

The histology of this retinopathy was described by RIEHM in 1927. He injected various quantities of Septojod into rabbits. Even where there were no visible changes macroscopically he found that the internal limiting membrane was raised by exudate in the underlying tissues. With higher dosage the exudate was seen to extend between the pigment epithelium and the sensory epithelium. The rods and cones dissolved, the inner nuclear layer disappeared and scattering of pigment occurred.

Experiments with Septojod in rabbits, performed by SALLMANN in 1933, showed which constituent of this preparation has the retinotoxic action. Pregl's solution contains $\mathrm{NaI}, \mathrm{NaOr}, \mathrm{NaHCO}_{3}, \mathrm{NaCl}$ and free $\mathrm{I}_{2}$. It was found that $\mathrm{NaOI}$ 
(sodium hypoiodite) produced the same histological changes in rabbits as those described by RIEHM. SALLMANN also found that sodium hypochlorite and sodium hypobromite, although they could not be injected intravenously in the same quantities as sodium hypoiodite because of the rapid damage they cause to the vessel wall, in smaller quantities also caused damage to the neural epithelium.

In animal experiments destruction of the retina was obtained with sodium iodate (SORSBY, 1941), sodium iodoacetate (NOELL, 1952 \& 1953) and sodium bromoacetate (LUCAS. NEWHOUSE \& DAVEY, 1957). NOELL included an ERG investigation in his study: he found that the ERG disappeared directly and completely after the injection of iodoacetate in monkeys, rabbits and rats.

\section{Retinotoxic effects of phenothiazines}

\section{N.P. 207}

In 1956 VERREX described the first ocular complications resulting from the use of a phenothiazine derivative. The preparation concerned was N.P. 207 (Sandoz), which had been distributed in small quantities to a few clinics for investigation.

The first complaints reported were disturbances in adaptation. In the fundus. if the total dose had been more than $30 \mathrm{gm}$, a severe retinopatky was seen. With a total dose of between 20 and $30 \mathrm{gm}$. three patients showed marked migration of pigment and in five cases the pigmentation was slightly abnormal. One patient in the group which had received less than $20 \mathrm{gm}$. showed marked pigment anomalies, the other patients in this group showed slight anomalies or had a normal retina.

In the slight cases the retina sometimes had the appearance of a pepper-andsalt fundus. Using the fundus contact glass the pigmentations were seen to be in and under the deep layers of the retina. Further particulars about this investigation and its results were not given.

In the subsequent discussion RINTELEN reported also having found pigment anomalies in twenty-four of a group of sixty-two patients treated with N. P. 207. In fifteen cases a more extensive examination was possible. Dark adaptation was disturbed in all cases to a greater or lesser degree. A few patients had visual field defects and disturbances in colour vision. The visual acuity was unaffected. The fundus picture did not improve after the treatment was stopped, but improvement was seen in the dark adaptation and the visual field. 
These findings led RINTELEN to examine patients who were being treated with chlorpromazine. He found no abnormalities in the fundus and the dark adaptation and visual fields were also normal.

In the further discussion on VERREY's report HEIM stated that, in $90 \%$ of a group of 120 patients treated with N. P. 207, he had seen peripapillary oedema which later became finely pigmented. The duration of the treatment varied from two to six months and the dosage was $100-500 \mathrm{mg}$. per day.

RINTELEN, HOTZ and WAGNER reported in 1957 the complete functional recovery of the fifteen patients described above. The appearance of the fundus, however, was not changed.

In rabbits, rats, guinea pigs and dogs no pigmentary changes in the fundus were seen after giving N. P. 207. WAGNER had already come to this conclusion in 1956, when he reported that N. P. 207 had no effect on the retina of animals. MEIER-RUGE's investigations on cats, however, have shown that this conclusion was not justified.

The first colour photographs of the retinopathy caused by N. P. 207 were made by GOAR \& FLETCHER in 1957. Of 34 patients who had been treated, 28 had abnormal fundi. The patients" first complaints were deterioration of vision. night blindness and disturbed colour vision.

Eight patients had severe loss of vision $(\leqslant 1 / 10)$, marked visual field defects and extensive migration of pigment in the fundus. After the treatment had been stopped six patients regained reasonable sight, although the visual fields remained restricted; two, however, remained blind.

Four patients had less marked signs of retinopathy; in these cases, the restoration of function was nearly complete.

Sixteen patients had slight anomalies: blurred vision, some restriction of the visual field and slight pigment changes in the fundus. In this group recovery was complete after the therapy was stopped.

The daily dose given to these patients varied from $200-2,800 \mathrm{mg}$., the total dose from $900-56,000 \mathrm{mg}$. The duration of the treatment is not mentioned.

In the early stages of the condition GOAR \& FLETCHER saw hyperaemia of the optic disc and swelling of the arteries and veins. Within two weeks patches of pigment had appeared halfway between the disc and the equator.

Two patients from the most serious group were submitted to an extensive examination by BURIAN \& FLETCHER (1958). The first patient, a 19-year-old woman, had first been treated with chlorpromazine without result; the amount of this drug she had been given was not reported. She was then treated for a 
period of $61 / 2$ weeks with $42,300 \mathrm{mg}$. N. P. 207. She showed the complete pathological picture described above.

The second patient, a 31-year-old woman, also failed to react to chlorpromazine; the amount she had taken was again not mentioned. She was then given N. P. 207 for nine weeks: the total dose was $45,900 \mathrm{mg}$. She also presented the complete range of abnormalities as described above.

The visual field, examined with the Goldmann perimeter, was found to be severely restricted using a small white object or a larger red or blue object.

Dark adaptation, examined with the Goldmann-Weekers adaptometer, was seriously disturbed, the function of both the rods and the cones was affected. The curves obtained from N. P. 207 patients resembled those of patients with retinitis pigmentosa, except that the rod system was less severely affected.

The function of the rods and cones, as indicated by the ERG. was severely disturbed but not completely lost. The ERG of the first patient resembled that seen in congenital hemeralopia: photopic $x$-wave present, scotopic $b$-wave usually absent; however, after prolonged dark adaptation, a trace of the b-wave was seen with orange and blue light stimuli.

In the second patient no photopic $x$-wave was seen, only a negative deflection. After an hour's dark adaptation intense red light flashes, as selective stimulus for the cone system, produced a response without an $x$-wave. Bluc light, a more or less selective stimulus for the scotopic system, and white light stimuli gave rise to a b-wave of moderate amplitude.

These results of the administration of N. P. 207 led to its immediate removal from the market and it has subsequently only been used for animal experiments.

In these publications mention is made several times of the variability of the symptoms in patients who had received approximately the same dose of N.P. 207. It is important to note that thesc patients had previously taken phenothiazine preparations, usually in the form of chlorpromazine. The daily dose, total dose and duration of the chlorpromazine therapy are not mentioned in any of the publications. Perhaps these particulars would give an explanation of the varying degrees of retinopathy found in patients treated with N. P. 207.

\section{Thioridazine (Melleril)}

WEEKLEY, POTYS. REBOTON \& MAY described in 1960 severe retinopathy in four patients from a group of 29 who were treated with large doses of thioridazine (Melleril). The total dosage given to these 29 patients varied from $1.2 \mathrm{gm}$. to 
101.1 gm.: the duration of treatment varied from 4 to 181 days; the largest daily dose was $4 \mathrm{gm}$.

This phenothiazine preparation is closely allied to N. P. 207, and like N. P. 207 fails to produce the undesirable side-effects of chlorpromazine, such as extra-pyramidal hyperkinesia, allergic reactions, dysfunctions of the liver and orthostatic hypotension (MAY, SELYMES, WEEKLEY \& POTTS, 1960).

Two of the four patients with retinopathy had severe loss of vision as the result of pigmentations in the macular area; these had taken a total dose of thioridazine of $101 \mathrm{gm}$. and $100.2 \mathrm{gm}$. respectively. The other two patients. with a total dose of $98 \mathrm{gm}$. and $85.4 \mathrm{gm}$. respectively, showed no deterioration of vision.

In one patient a haemorrhage was seen near a retinal vessel. In the other patients no anomalies of the optic disc or blood vessels were seen.

Examination with monochromatic light showed that the pigmentations were situated in the deep layers of the retina.

An ERG was made from two patients on the 75 th and 89 th days after the start of the therapy. No response to light flashes could be seen after five or ten minutes of dark adaptation. The ERG was again recorded on the 327 th day after the start of the therapy, the thioridazine administration having been stopped in the meantime. An ERG response was now obtained, but its amplitude diminished rapidly after a few flashes and did not recover within an hour.

Investigation of the visual fields and dark adaptation yielded quite unreliable results owing to the patients' psychological condition.

MAY, SELYMES, WEEKLEY \& POTTS suggest $1600 \mathrm{mg}$. thioridazine per day as a safe therapeutic dose and $\$ 00 \mathrm{mg}$. per day as a safe maintenance dose.

MORRISON in 1960 reported a 17-year-old patient with disturbed dark adaptation after taking thioridazine. $30 \mathrm{gm}$. had been taken over a period of $21 / 2$ months: for a period of 12 days the patient had been taking 1,200 mg. per day. The results of eye examination were negative, further details of the examination are not given. When the therapy was stopped the complaints disappeared.

scorr in 1963 described a 19-year-old male schizophrenic with extensive retinopathy following treatment with thioridazine. During a period of hospitalization he was given $50 \mathrm{gm}$. of thioridazine in three months. The average daily dose was $550 \mathrm{mg}$. Nine months later the patient was readmitted to hospital: in two months 'time he was given a total dose of $118.5 \mathrm{gm}$. thioridazine; the average daily dose was $1,975 \mathrm{mg}$. Deterioration of vision and visual field defects developed. Three weeks after the therapy had been stopped scorx saw pigmentations 
in the fundus, central and peripheral but not at the extreme periphery. Three weeks later dark adaptation was disturbed. Six months after stopping treatment the vision and retinal pigmentations were unchanged. The critical ficker frequency (CFF) was normal in the central area up to $20^{\circ}$ from the centre, peripherally it was markedly abnormal. The dark adaptation curve registered the function of the cone system only. The ERG, however, was normal. Later the vision improved considerably, although scotopic vision remained poor. The pigmentations remained.

APPELBAUM in 1963 examined 77 patients who were being treated with thioridazine. The daily dosage varied from 100 to $600 \mathrm{mg}$. and the duration of the treatment from 1 to 14 months. The examination consisted of funduscopy under narcosis. No pigmentary anomalies of the retina were seen.

CONNELL et al. in 1964 described a 37-year-old woman with retinopathy after taking $40 \mathrm{gm}$. thioridazine. The largest daily dose had been $1.2 \mathrm{gm}$., the treatment had been continued for forty days. She had also been given $100 \mathrm{mg}$. imipramine and $5 \mathrm{mg}$. benztropine methanesulphonate per day. The visual acuity had deteriorated and the visual fields were markedly reduced. Visible changes in the fundus did not appear until later. Colour vision was normal. The ERG showed abnormalities of both the photopic and the scotopic systems. The dark adaptation curve also indicated reduced function of the rods and cones. Vision improved after the treatment was stopped, the scotomata became smaller but the retinopathy remained.

FINN in 1964 reported on a 23-year-old patient suffering from an acute schizophrenic psychosis who developed a retinopathy following thioridazine treatment. The total dose taken was $50-60 \mathrm{gm}$. over a period of 56 days; the largest daily dose was $1.4 \mathrm{gm}$. The visual fields were concentrically severely reduced. Vision in the dark was poor but dark adaptation curves were not made. The visual acuity was poor. After the treatment was stopped the visual acuity recovered and the scotomata became smaller. The abnormal pigmentation in the fundus remained.

HAGOPIAN et al. in 1966 examined 164 patients who were being treated with thioridazine. Eight of these patients were taking a daily dose of more than $1,800 \mathrm{mg}$.; five of these had deterioration of vision and extensive migration of pigment in the fundus. Before the thioridazine treatment these patients had taken drugs and the authors could not exclude the possibility of an additive or cumulative effect. When the thioridazine was discontinued vision improved but the pigmentations remained. 


\section{Chlorpromazine (Largactil)}

BAUMANN in 1957 reported on 35 schizophrenics who were being treated with chlorpromazine. Their ages varied from 31 to 65 years, the duration of the treatment from 6 months to $21 / 2$ years and the total amount of chlorpromazine they had taken from 25 to $248 \mathrm{gm}$.

The Goldmann-Weekers adaptometer was used to investigate the dark adaptation. The visual fields were determined with the Goldmann perimeter. Colour vision was examined with the Ishihara pseudo-isochromatic plates. The fundus was carefully studied by direct and indirect ophthalmoscopy in homatropine mydriasis. No abnormalities were found in 24 cases.

The results of the examination of the other 11 patients were reported in more detail. Nine patients had slightly abnormal visual fields and dark adaptation. which could be explained by opacities in the media or the patients mental condition. It was possible that two patients had slight retinopathy, consisting of exaggerated pigment mottling.

According to this author, chlorpromazine in normal dosage does not cause retinal damage; the dosage, however, is not mentioned.

BUSCH, BUSCH \& LEHMANN in 1963 found no ocular abnormalities in 363 patients who were being treated with chlorpromazine and promethazine. The investigation was limited to the determination of the visual acuity and refraction and to funduscopy; whether the latter was performed in mydriasis is not mentioned. The daily dosage varied from 50 to more than $250 \mathrm{mg}$. of the phenothiazine preparation, the duration of the treatment was from two months to more than three years. The total dose taken by each patient was not reported.

SIDDALL (1965) described anomalies of the conjunctiva, cornea, lens and retina in fifty patients treated with chlorpromazine. A dark film over the retina was seen in nearly all cases. In eleven cases there was definite granularity; in four cases there was clumping of pigment: one of these clearly showed migration of pigment in the fundus. Two of the patients with retinal anomalies had a reduced visual field and one poor vision - this was partly due to opacities in the cornea and lens. The author expects ocular complications to occur after about twenty months" treatment with a daily dose of $800 \mathrm{mg}$. chlorpromazine.

RAB, ALAM \& SADEQUZZAMAN (1969) described atrophy of the optic nerve and retinopathy in both eyes of a 27 -year-old man following chlorpromazine treatment. The daily dosage had been $500 \mathrm{mg}$. for eleven weeks and $150 \mathrm{mg}$. fnr one week. 


\section{Other oculo-toxic effects of phenothiazine derivatives}

In 1963 BOCK \& SWAIN examined 27 patients who, for two years or longer, had been taking a minimum daily dose of $200 \mathrm{mg}$. chlorpromazine. They reported incidentally in one patient 'fine, powdery white spots on the anterior (lens) capsule in the central pupillary area, a phenomenon which was to be reported very frequently in later publications.

In two patients they found that the intra-ocular pressure was raised. Their own observation on 1000 unselected patients was that chronic glaucoma is found in $1.9 \%$. In one case they also found marked migration of pigment in the fundus, although this patient, who had been given a daily dose of $50 \mathrm{mg}$. chlorpromazine for three years, did not fulfil their criteria for dosage. The authors emphasized the "atropine-like' action of chlorpromazine and the importance of measuring the ocular pressure of patients who are being treated with this preparation.

BIERENT, however, in 1954, and SANA (1958) found that chlorpromazine lowered the intra-ocular pressure in acute glaucoma. Lowering of the pressure was also obtained by PAUL \& LEOPOLD (1956) in cats and by CONSTANT \& BECKER (1956) and RAMOS, CALDEIRA \& RAMOS (1967) in rabbits by means of intravenous or intracisternal injection of this preparation.

RAMOS, GIESBRECHT, CALDEIRA \& RAMOS (1969) found a decrease in the chloride and sodium concentration of the aqueous in rabbits treated with chlorpromazine. The potassium content of the aqueous was not significantly decreased. although there was a significant lowering of the potassium content of the serum. The authors consider that the effect of chlorpromazine in lowering the ocular pressure is due to the action of the drug on the central nervous system.

In 1964 GREINER \& BERRY described slate-blue discoloration of the skin, where it was exposed to sunlight, in female patients who were being given an average daily dose of 500-1,500 mg. chlorpromazine (confirmation of PERror's observation in 1962). The cause of the discoloration was accumulation of melanin in the superficial layers of the dermis, especially around the blood vessels. Examination of the eyes of these patients revealed brown discoloration of the sclera and yellowish-white granules in the stroma of the cornea, in the central area. The authors also saw yellowish-white granules in the form of a star centrally situated on the anterior surface of the lens. Abnormalities of the retina were not reported.

In the same year GREINER \& NICOLSON reported the unexpected death of twelve 
young adults, who had been receiving prolonged chlorpromazine treatment. Five of them showed skin discoloration: two of these had complained of deterioration of vision but the cause of this is not mentioned. On autopsy melanin was found in the macrophages of the dermis, in the reticulo-endothelial system, and in the parenchyma cells of the liver, kidneys and lungs. The eyes of these patients were not examined. The authors ascribe the melanosis to accelerated destruction of adrenalin and nor-adrenalin and reduced production of melatonin. Melanin is formed in the cytoplasm of melanocytes by oxidation of the amino-acid tyrosine in the presence of the enzyme tyrosinase. Its production is under hormonal ar $d$ neural control. The amount of pigment in a particular melanocyte is determined by the balance of darkening and lightening factors. The most important darkening factors are alpha and beta melanocyte stimulating hormones (MSH), androgen, oestrogen, and thyroid extract. Lightening factors include: adrenalin, nor-adrenalin, serotonin and melatonin, which is present in the pineal body and in peripheral nerves. Phenothiazines decrease the release of adrenalin and nor-adrenalin. There will be a relative excess of MSH, with overproduction of melanin. Furthermore, by inhibiting sympathetic nervous system function, phenothiazines may impair melatonin production".

In a later article GREINER, NICOLSON \& BAKER (1964) described a possible treatment for this melanosis. The enzyme tyrosinase plays an important rôle in the formation of melanin. Tyrosinase contains copper. If a chelating agent is given which combines with the copper, this reduces the activity of the tyrosinase. The authors used d-penicillamine ( $\beta, \beta$-dimethylcystine) as chelating agent for copper:

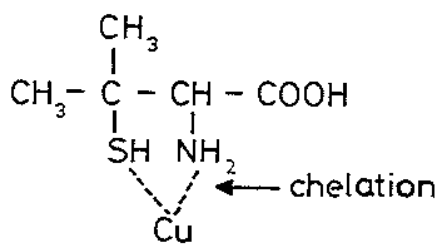

This is a break-down product of penicillin and is used in hepatolenticular degeneration (Wilson's disease), siderosis of the eye, etc.

Six patients were treated with d-penicillamine: they were also instructed to stay in the dark or wear sun-glasses, measures which should stimulate the production of melatonin. In addition, four of the six patients were given no more phenothiazines. These four patients showed a remarkable loss of colour after 
four weeks. Of the two patients who had continued with phenothiazine treatment while taking penicillamine and remaining in the dark, one showed a slight loss of colour and the other was unchanged. As controls two patients who were given neither penicillamine nor chlorpromazine remained for four weeks in the dark: these patients showed some loss of colour, but to a lesser extent than the first four patients.

ZELICKSON \& ZELLER (1964) described eight patients with discoloration of the skin, where it was exposed to the sunlight, following treatment with phenothiazine derivatives. In one case the discoloration was also seen behind the patient's glasses. This led the authors to conclude that light above the wave length of $3200 \AA$ plays a rôle in the discoloration. Three of these eight patients had increased pigmentation, and also areas of depigmentation, in the fundus.

BAN \& LEHMANN (1965) found typical skin pigmentation in ten women and five men who had been taking chlorpromazine. The daily dose varied from 300 to $1,000 \mathrm{mg}$.; some patients were also being given other phenothiazine preparations at the same time. The duration of treatment varied from two to nine years. Thirteen of these patients were found to be photosensitive on exposure to ultraviolet light for one minute. Some other patients who had been taking other phenothiazine preparations were also found to be photosensitive.

Anomalies of the conjunctiva, cornea and lens typical for chlorpromazine were found in fourteen of the fifteen patients. Ten patients who had been taking other phenothiazine preparations but no chlorpromazine showed anomalies of the lens and cornea in eight cases but no conjunctival pigmentations. There was a correlation between the severity of the ocular complications and the dosage of the phenothiazines. The retinae of these patients were probably normal, but this is not specifically stated.

MARGOLIS \& GOBLE in 1965 found lens anomalies in eight of a group of thirtyone patients who were being treated mainly with trifluoperazine. With the slitlamp they saw 'dust-like, red-brown, granular particles in the anterior lens cortex, near the lens capsule, dispersed in stellate or occasionally in a dendritic fashion". The intra-ocular pressure, visual acuity and visual fields were normal. Abnormal pigmentation in the retina was not seen. In their conclusion. they make the suggestion, seeing that these patients had been taking various phenothiazine derivatives. that all phenothiazine preparations may give rise to ocular complications.

BARSA, NEWTON \& SAUNDERS (1965) examined a group of 658 female patients of whom 145 had opacities in the lens as the result of phenothiazine treatment. 
The patients were divided into four groups according to the density of the opacities. In the group with the densest lens opacities corneal opacities were also always present; this was the case in 33 cases. The percentage of patients with raised intra-ocular pressure was not above normal. No pigmentary changes were seen in the fundus. The authors urge the importance of regular control of the eyes of patients who are being treated with phenothiazine preparations, a suggestion which is also supported by POTYS \& MEIER-RUGE.

SANDVIG (1965) examined twenty-seven patients who were being treated with chlorpromazine and found in twenty-three cases typical anomalies in the lens and cornea. Of these twenty-three, twenty were female and three male. Seventeen patients could be examined ophthalmoscopically; the fundi were normal. The average daily dose varied from 400 to $2.400 \mathrm{mg}$.

WETTERHOLM, SNOW \& WINTER in 1965 examined 384 male patients who had been receiving chlorpromazine treatment. The average daily dose varied from 300 to $1,600 \mathrm{mg}$., the total dosage from 1.000 to $2,000 \mathrm{gm}$. In $125 \mathrm{cases}, 32.5 \%$. the authors found typical opacities in the cornea and lens. One patient had a red-green colour defect. Three showed 'a light pigmentary mottling of the fundus due to increased choroidal pigmentation". In five cases an ERG could be made: it was normal in all cases.

CAIRNS, CAPOORE \& GREGORY in 1965 described four cases of diffuse opacities in the stroma of the cornea, associated with lens opacities, following the administration of chlorpromazine. The fundus and the optic nerve were normal.

MCCLANAHAN et al. (1966) described eleven patients with conjunctival discoloration and lens pigmentations resulting from chlorpromazine treatment and one patient with retinal anomalies caused by thioridazine.

JOHNSON \& BUFFALOE in 1966 described epithelial lesions of the cornea. These had also been reported by SIDDALL (1965). The keratopathy was limited to the lower half of the cornea and consisted of white, grey and brown lines. The average daily dose of chlorpromazine given to these patients was $2,000 \mathrm{mg}$.

DENCKER \& ENOKSSON in 1966 reported fourteen patients with skin pigmentations following chlorpromazine treatment: ten of these also had typical corneal and lens anomalies. No mention was made of the retina.

In 1966, EDLER examined 261 patients who had been receiving phenothiazine therapy. Fifty-two patients had anomalies of the lens and cornea and fourteen had a pepper-and-salt fundus. In 153 cases the author saw brown deposits of pigment on the anterior surface of the iris. Naevi, sometimes resembling melanomata, were also seen. In one case the corneal precipitates disappeared with local 
cortisone treatment, but a cataract developed, probably as a result of the cortisone eye-drops. When the drops were stopped the precipitates reappeared. When both the chlorpromazine and the eye-drops were stopped the corneal precipitates disappeared and the cataract became less dense. A rise in intra-ocular pressure was not found.

Articles published by MATHALONE in 1965, 1966 and 1967 describe the examination of 462 patients who were being treated with chlorpromazine. He found a correlation between corneal and lens opacities on the one hand and the duration of the therapy and the dosage of the drug on the other hand. The intra-ocular pressure was not raised. An EOG was made in thirteen cases; the LP/DT ratio was low but. according to the author, still within the limits of normal. In two cases pigmentations were seen in the fundus. Ten patients were treated with d-penicillamine for eight months, in eight cases the chlorpromazine treatment was also stopped. Of these eight, two showed improvement in the lens condition and two in the keratopathy. As the results were not spectacular the penicillamine treatment was stopped.

CAMERON (1967) considered that ultra-violet light of wave-length greater than $3,200 \AA$ is responsible for the pigmentation of the skin. cornea and lens. In the opinion of the author, light from the sky is focused onto the anterior part of the eye, and ultraviolet light mainly onto the anterior lens capsule, so that lens changes may be expected to be a sensitive sign of phenothiazine intoxication.

HOFMAN (1967) described 6 female patients with blue discoloration of the face. Opacities in the cornea and lens were found in 4 patients. one of whom also had brown pigmentations in the sclera in the palpebral fissure.

KASSMAN \& WETTERBERG (1967) found lens opacities in eleven patients who had each taken a total dose of more than $600 \mathrm{gm}$. laevomepromazine. The urine of these patients contained a porphobilinogen-like substance. The authors are going to investigate the significance of this further.

NOURI \& CUENDET (1968) examined 225 patients and found lens opacities in 54 cases $(24 \%)$ and corneal opacities in 12 cases $(5 \%)$. The patients had teen mainIy treated with chlorpromazine; the daily dose varied from 25 to $300 \mathrm{mg}$. and the total dose from 300 to $1,530 \mathrm{gm}$. In one case retinopathy was seen.

\section{Animal experiments}

In 1966 MEIER-RUGE \& CERLETTI obtained in cats who were being treated with piperidylchlorophenothiazine (N. P. 207), pigment changes in the fundus, which 
were similar to those produced in man by this preparation. Initially finelyspeckled greyish-brown pigmentations appear, which become coarser if the administration of the drug is continued. The pigmentation is caused by accumulation of lipoids in the pigment epithelium; the lipoid comes from the distal segment of rods which have been destroyed. The authors established by means of histological staining that reduction of adenosine triphosphatase precedes the destruction of the distal rod segment. The activity of lactic dehydrogenase, alkaline phosphatase and phosphomonesterase $I$ is also reduced. Acid hydrogenase is unaffected: "this enzyme seems to be retained as long as the visual cell survives, so that the distal rod segment is able to regenerate".

MCDONALD, SNELL \& LERNER (1967) administered chlorpromazine to guinea pigs and irradiated them with ultraviolet light. They observed small white dots in the anterior subcapsular area and also in the posterior cortex of the lens. The opacities resembled those seen in man during chlorpromazine therapy.

BEEHLER, ROBERTS \& SALEM (1968) obtained an increased frequency of retinal detachments in dogs living in a high concentration of oxygen, if they were given chloroquine or phenothiazine derivatives. They ascribed this to degenerative changes in the retina caused by these drugs.

MEIER-RUGE, in his excellent monograph (1967) describes selective absorption of the phenothiazines on the melanin of the choroid. He therefore concludes that every phenothiazine derivative is more or less toxic for the retina. Ports also comes to the same conclusion.

To summarize, from the literature it appears that phenothiazine derivatives, given in high dosage and for long periods of time, can give rise to:

a. discoloration of the skin where it is exposed to the sunlight;

b. discoloration of the conjunctiva;

c. discoloration of the sclera:

d. opacities in the cornea (epithelium, stroma, endothelium):

e. opacities of the lens near the anterior capsule;

f. retinopathy in the form of:

1. migration of pigment and

2. disorders of retinal function, both subjective (visual acuity, visual fields, dark adaptation, colour vision) and objective (ERG, EOG). 


\section{PRESENT STUDY}

\section{Material}

The patient material for this study came from two psychiatric hospitals: Delta Ziekenhuis in Poortugaal (Rotterdam) and Stichting Rosenburg in The Hague.

Male and female patients, who were being treated with phenothiazine preparations, were examined. No selection was made on the basis of duration of treatment, size of daily dose or nature of the phenothiazine preparation being taken. Usually various derivatives had been prescribed in varying dosages in the course of the treatment, sometimes with a period without medication between. On p. 32 further particulars are given about the prescribed preparations.

Our original intention was to restrict the study to patients under 45 years of age, in order to avoid confusion between retinal changes caused by phenothiazine preparations and those due to arteriosclerosis. When it appeared, however, that this would make the number of patients examined in Stichting Rosenburg too small, it was decided to include patients above 45 years of age in the study. Furthermore, the objections to this carried less weight, as the experience gained in the recognition of the retinal changes caused by phenothiazine treatment enabled us to distinguish them more easily from other types of fundus anomaly.

TABLE I

Age and sex distribution of 541 patients

\begin{tabular}{|c|c|c|c|c|c|}
\hline Males & No. & $\%$ & Fermales & No. & $\%$ \\
\hline$\leqslant 45$ years & 160 & 29.6 & $\leqslant 45$ years & 129 & 23.8 \\
\hline$>45$ years & 100 & 18.5 & $>45$ years & 152 & 28.1 \\
\hline Total & 260 & 48.1 & Total & 281 & 51.9 \\
\hline
\end{tabular}

The whole study included 561 patients. Twenty of these were found to have abnormal fundi due to other causes than phenothiazine therapy and were excluded from the study. The age and sex distribution of the remaining 541 patients is shown in Table $\mathrm{I}$.

\section{Method}

As the examination of 561 patients by one man would have taken too much time, the help of The Netherlands General Association for Prevention of Blindriess was 
called in. The Association allowed its Rotterdam field-workers to work on this study for two years. These field-workers are doctors studying to be ophthalmologists at one of the Dutch Eye Hospitals, who are lent to the Association for Prevention of Blindness for a period of six months for research work. In this way, examination of the patients in Delta Ziekenhuis was undertaken by the author's colleagues Alkemade*, Craandijk, Rozemeijer and Miss Mertens. The examination of the patients in Stichting Rosenburg was performed by the author. The medical staffs of the Eye Hospital in Rotterdam, Delta Ziekenhuis and Stichting Rosenburg offered all possible assistance, and the nursing staffs of the last two hospitals were extremely helpful. I am very grateful to all these people.

Discussions between the field-workers and the author took place regularly in order to ensure that the interpretation of the results obtained should be uniform. Also patients were often examined together.

A scheme for a standard examination was drawn up, which was applied as far as possible to all patients. Considering their mental state, however, it was to be expected that in many cases it would not be possible to obtain reliable results from all the tests.

The examination was carried out in two or three sessions and covered the following points:

1. case history, with special emphasis on the presence or absence of photosensibility:

2. external examination: inspection of the eyes, eyelids and skin and the colouring of the patient (dark or blonde);

3. slit-lamp examination, where possible (Haag Streit. magnification $25 \times$ ):

4. measurement of the intra-ocular pressure (where possible) by means of the Schiötz tonometer or the Goldmann applanation tonometer:

5. funduscopy in mydriasis, by both the direct and the indirect method; rapid mydriasis of short duration was obtained by means of Mydriaticum (Laboratoires Chibret, formula: Acid. tropic. N-ethyl-N-(r-picolyl)-amid. $5 \mathrm{mg}$ : Natr. sulfuric.-phenylhydrargyr. nitric. $0.01 \mathrm{mg}$ : aqua ad $1 \mathrm{mI}$ ):

6. investigation of the retinal function:

a. visual acuity, with and without correction;

* The patients described by ALKemade $(1966,1968)$ are included in this study. 
b. colour vision, by means of the Ishihara pseudo-isochromatic plates and the Hardy-Rand-Rittler test:

c. an electro-oculogram (EOG) was made on selected cases; the selection was dependent upon whether the patient was calm and cooperative and whether he could shift his gaze adequately from right to left.

The method of obtaining and recording the EOG was that described by HENKES et al. in 1968. In electro-oculography the standing corneo-fundus potential is measured indirectly by means of electrodes which are placed alongside the
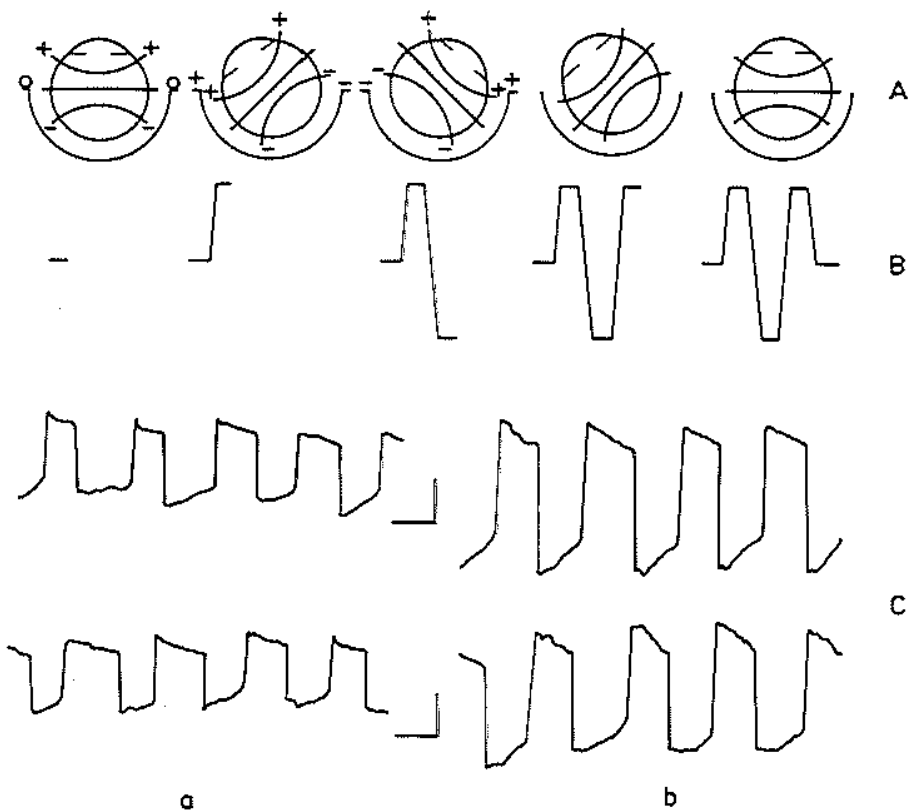

C

Fig. 1

(A) Principle of recording of standing potential based upon alterations in the electric field resulting from eye movements.

(B) Resulting changes in potential between the electrodes.

(C) The upper trace of the original graphs shows movements of the right eye; the lower one of the left eye. The amplitude of the initial vertical excursions is a measure of the height of the standing potential.

(a) after 12 minutes dark adaptation: (b) $\$$ minutes after re-illuminating the retina.

Calibration bars: 500 microvolts, 500 msec. (after ARDEN, BARRADA \& KELSEY, 1962) 
external and internal canthi of both eyes. When the eyes are moved a change in potential between the two electrodes can be recorded (see Fig. 1). This change in potential is small in dark adaptation and larger in light adaptation (light peak/dark trough - LP/DT - ratio).

The EOG gives information about the quality of the choriocapillaris, Bruch"s membrane, the pigment epithelium and the rods and cones of the retina (ARDEN, 1962). The lower limit of normal for the LP/DT ratio was taken as $165 \%$ as suggested by HENKEs el al. (1968) and KELSEX (1967).

As was to be expected. in many cases either it was impossible to make an EOG altogether or the results were unreliable. In the majority of cases it was also impossible to investigate the visual fields or dark adaptation.

The psychiatrist's diagnosis was noted in all cases.

For all patients careful note was taken of the drugs which had been given, the length of time they had been taken and the dosage which had been prescribed. From these data the total dosage and the average daily dose of the preparations were calculated for each patient. Particulars of therapeutic measures taken during earlier periods of hospitalization in other hospitals were unfortunately difficult to obtain and not very exact.

The phenothiazine preparations which had been taken by the patients included in this study were: promazine, chlorpromazine, trifluopromazine, laevo-mepromazine, promethazine, mepazine, thioridazine, propericiazine, perazine, prochlorperazine, trifluoperazine, thioproperazine, perphenazine and thiopropazate.

OBSERVATIONS

Skin \& Eyelids

Slate-blue discoloration of the exposed skin was seen and in these cases the eyelids were also discoloured. Discoloration was not seen in folds of the skin into which the sunlight could not penetrate.

\section{Conjunctiva}

Brown pigmented stains were seen in the conjunctiva. They had a granular appearance and were situated in the palpebral fissure usually near the limbus corneae. 

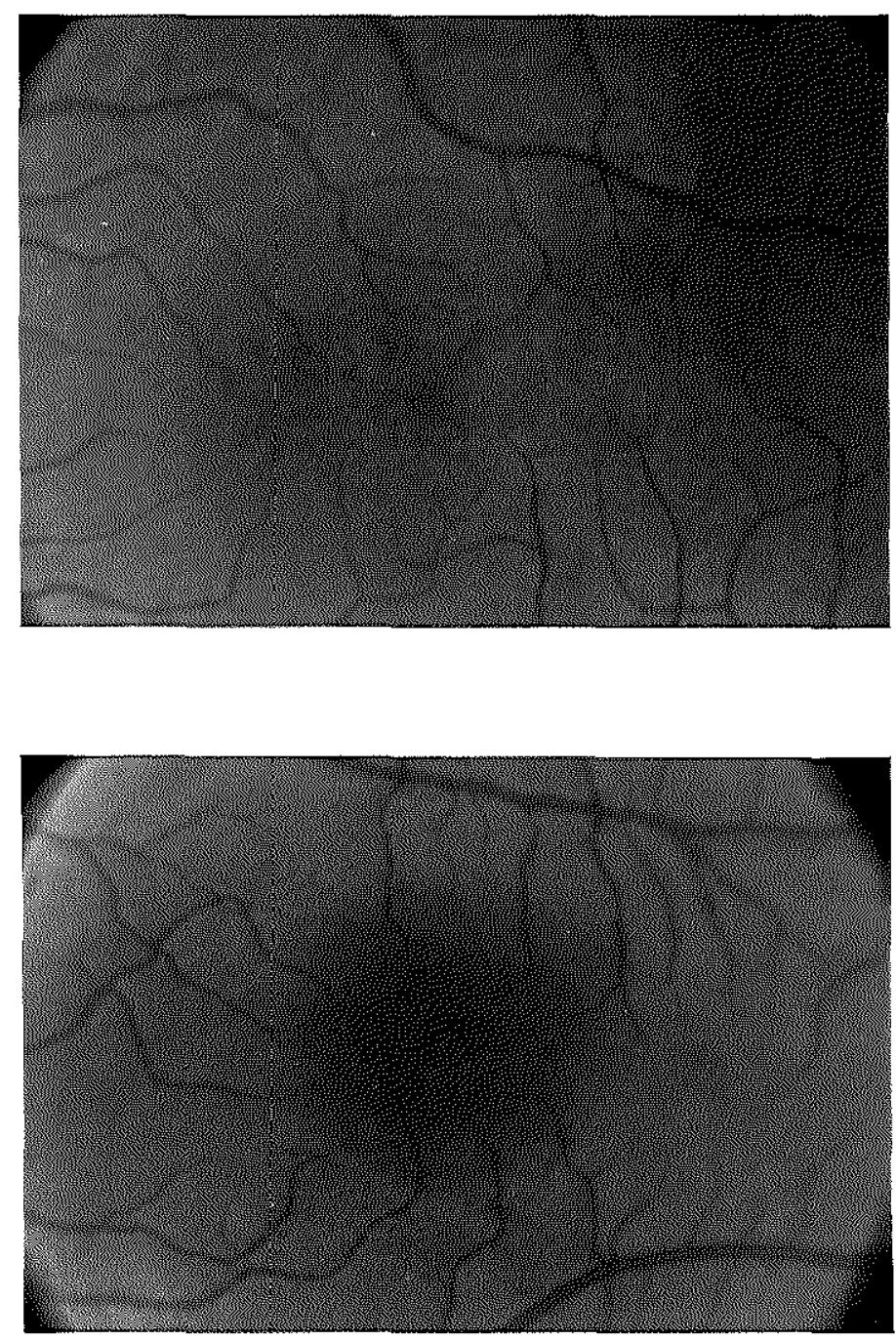

Central phenothiazine retinopathy 

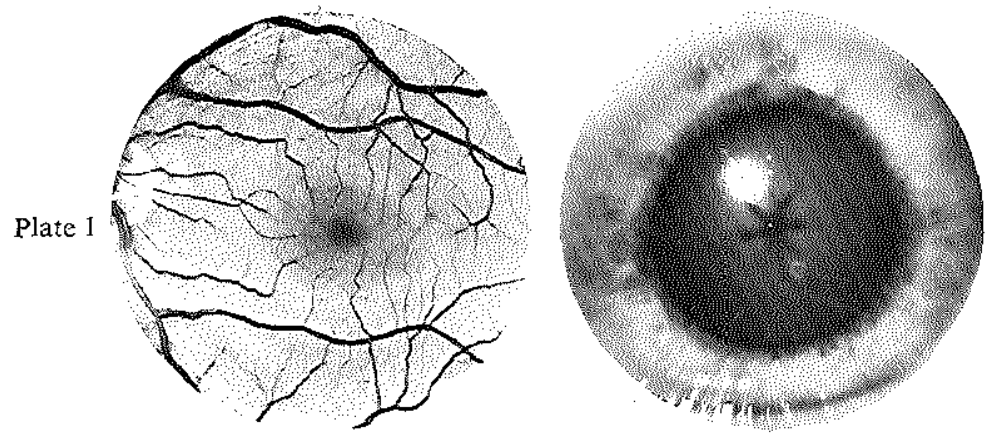

Plate 2
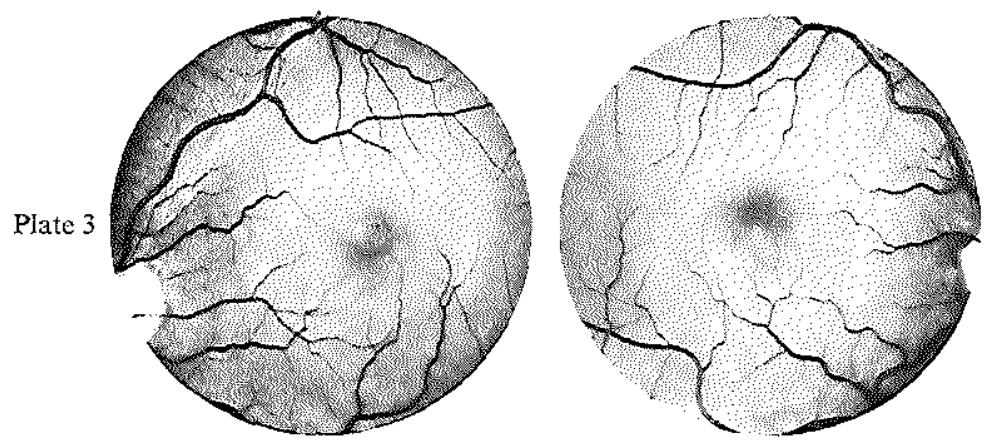

Pjate 4
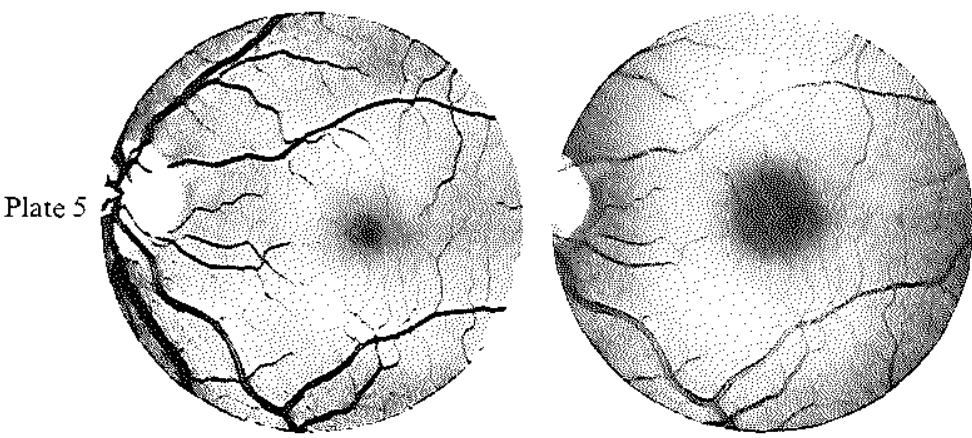

Plate 6

Plate 1

Normal pattern of retinal pigmentation

Plate 2

Star-shaped opacity on lens

Plates 3 \& 4

Phenothiazine retinopathy (central); right and left eyes of one patient

Plate 5

Central retinopathy photographed with orthochromatic film

Plate 6

Same fundus photographed with panchromatic film 


\section{Cornea}

Fine yellowish-white granules were seen in the deeper layers of the corneal stroma, in Descemet's membrane and in or on the endothelium. They resembled very fine pollen and were always centrally situated, never at the limbus.

\section{Lens}

'Pollen deposits" were also found on the anterior surface of the lens and under the surface. Occasionally the lens opacities were star-shaped. The yellowishwhite granules were again found in the centre or sometimes just below the centre.

\section{Retina}

For the sake of clarity a description of the normal retina (DUKE-ELDER; BALLANTYNE \& MICHAELSON) is given before proceeding to the anomalies found during this study.

The normal retina is red in colour when examined with white light. The red colour is produced by the light reflected from the choroid and varies with the degree of pigmentation of the choroid. The choroidal pigmentation corresponds with the generalized degree of pigmentation of the individual.

The choroidal pigment can be seen as dark polygonal areas between the choroidal vessels, which, however, are usually not visible. These areas are very pronounced in dark individuals, the so-called tigroid or tesselated fundus.

The retinal pigment has practically no influence on the colour of the fundus. The amount of pigment in the retinal epithelium shows very little individual variation. except in the case of albinos. If the pigment is deficient the choroidal vessels can be seen against the background of the underlying sclera.

The pigment epithelium of the retina appears as a fine granulation over the fundus. At and around the macula this is difficult to see because of its very regular distribution. At the periphery, near the ora serrata, the granulations are coarser and less regular and can be more easily seen.

According to HOGAN \& ZIMMERMAN the pigment epithelium consists of a layer of regularly arranged hexagonal cells containing rod-shaped melanin granules in their inner part. These granules become rounded in the process of aging.

In this study we found that phenothiazine derivatives produced coarsening of the retinal pigmentation and patches of depigmentation. Where the coarsening 
was discernible but not marked, the term "slight retinopathy" was used; where it was very marked and the choroidal pigmentation was also affected, the condition was called "severe retinopathy"*. The foveolar reflex was usually absent, even in the slight cases. The pigmentations were not particularly marked at the foveola. In the majority of cases the whole fundus was equally affected by the pigmentary changes: this was described as "central and peripheral" localization of the retinopathy. In a very much smaller number of cases the coarsening of the pigmentation was only seen at the periphery or only in the central area: this was described as either "peripheral" or "central" retinopathy. The pigmentations always had a regular pattern. A depigmented area round the macula, like the 'bull's eye' seen in chloroquine retinopathy, was not found. The optic disc and blood vessels were normal.

In the group of patients above the age of forty-five, it was sometimes difficult to distinguish the pigmentary changes in the fundus due to arteriolosclerosis from those which are seen in phenothiazine retinopathy. In our opinion, however, there are differences: the pigmentations which occur as the result of arteriolosclerosis, particularly of the choroid, are coarser and more irregularly distributed and are darker in colour. According to PILLAT (1950) and BALLANTYNE \& MCHAELSON (1962) arteriosclerotic pigmentary changes occur much more frequently at the periphery than at the macula. If there are clear signs of arteriolosclerosis to be seen in the retinal and choroidal vessels, this can also be an aid to the differential diagnosis. In some older patients both arteriolosclerotic and phenothiazine pigmentations were present; if this was thought to be the case the funduscopy was performed by more than one examiner, and if no agreement could be reached the patient was classified as not suffering from phenothiazine retinopathy.

\section{Electro-oculogram}

In an appreciable percentage of cases the EOG values were too low. These findings will be further discussed on p. 48 .

RESULTS

The patient material was too large to allow straightforward evaluation of the results obtained, so assistance was asked and obtained from the Statistical

* for definition of retinopathy see p. 52 . 


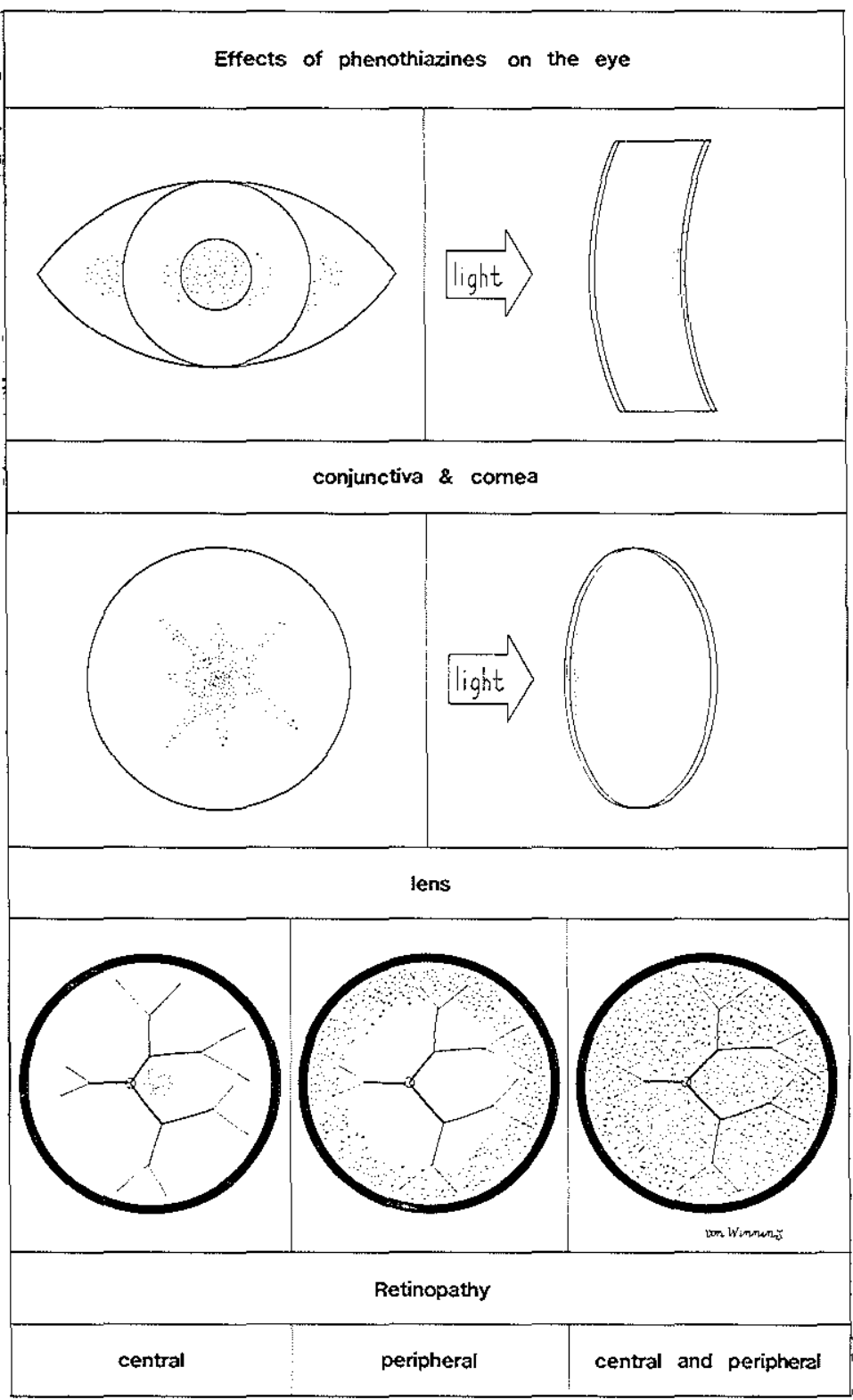

Fig. 2

Schematic representation of the toxic effects of phenothiazines on the eye, 
Bureau ABW-TNO. With their co-operation a code system was devised, which enabled us to deal with all the data mechanically. All the eye conditions found were given code numbers. This was also the case with the drugs used, the psychiatric diagnosis, the sex and age of the patient and the hospital in which the examination had taken place. The duration of the treatment, the dosage of the preparations and the average daily dosage were also registered. The code numbers were transferred to punch cards and, with the help of a Hollerith machine, a computer and statistical calculations the following results were obtained.

\section{Skin pigmentation}

In five women pathological pigmentation of the face, eyelids, etc. was seen $(0.9 \%)$.

\section{Photosensitivity of the skin}

In 49 cases a history of photosensitivity could be elicited, either from the patient himself or from others $(9.1 \%) .25$ women and 24 men were affected.

\section{Cornea}

Typical corneal opacities were found in 8 patients. 7 women and one man (1.5\%). These opacities could only be seen on slit-lamp examination.

\section{Lens}

Opacities in the lens were found in 46 patients ( $8.5 \%), 22$ women and 24 men. Except in the most pronounced cases these were also only visible with the slitlamp.

The correlation between the corneal and lens opacities and the total dose of phenothiazine preparations, the average daily dose and the duration of the treatment is given in Table II.

\section{Intra-ocular pressure}

It was possible to measure the intra-ocular pressure of 26 patients ( 52 eyes), 11 men and 15 women. Raised pressure $(25 \mathrm{~mm} . \mathrm{Hg}$ ) was found on the left eye of one man, the diagnosis was subsequently made of glaucoma simplex. 
TABLE II

Corneal and lens opacities

\begin{tabular}{|c|c|c|c|c|}
\hline $\begin{array}{l}\text { Total dose } \\
\text { in gms. }\end{array}$ & Males & Females & $\begin{array}{c}\text { Lens } \\
\text { opacities }\end{array}$ & $\begin{array}{l}\text { Corneal } \\
\text { opacities }\end{array}$ \\
\hline$<500$ & 9 & 9 & is & 2 \\
\hline $500-1,000$ & 7 & 7 & 12 & 3 \\
\hline $1,000-1,500$ & 6 & 5 & 12 & 2 \\
\hline$>1,500$ & 2 & 2 & 4 & 1 \\
\hline Total: & 24 & 23 & 46 & 8 \\
\hline $\begin{array}{l}\text { Average daily } \\
\text { dose in mgs. }\end{array}$ & Males & Females & $\begin{array}{c}\text { Lens } \\
\text { opacities }\end{array}$ & $\begin{array}{l}\text { Corneal } \\
\text { opacities }\end{array}$ \\
\hline$<100$ & 0 & 2 & 2 & 0 \\
\hline $100-200$ & 6 & 8 & 13 & 3 \\
\hline $200-300$ & s & 6 & 14 & 1 \\
\hline$>300$ & 10 & 7 & 17 & 4 \\
\hline Total: & 24 & 23 & 46 & 8 \\
\hline $\begin{array}{l}\text { Duration of } \\
\text { therapy in } \\
\text { months. }\end{array}$ & Males & Females & $\begin{array}{c}\text { Lens } \\
\text { opacities }\end{array}$ & $\begin{array}{l}\text { Corneal } \\
\text { opacities }\end{array}$ \\
\hline$<24$ & 1 & 1 & 2 & 0 \\
\hline $24-48$ & 1 & 3 & 4 & 1 \\
\hline $48-96$ & 11 & 7 & 18 & 3 \\
\hline $96-120$ & 5 & 4 & 9 & 1 \\
\hline$>120$ & 6 & 8 & 13 & 3 \\
\hline Total: & 24 & 23 & 46 & 8 \\
\hline
\end{tabular}

\section{Retina}

Retinopathy was found in 343 cases $(63.4 \%$ ). In the age-group below 45 years 160 of the 289 patients had this condition $(55.3 \%$ ), above the age of 45 it was seen in 183 of the 252 patients (72.6\%). See Fig. 3 and Table III. 


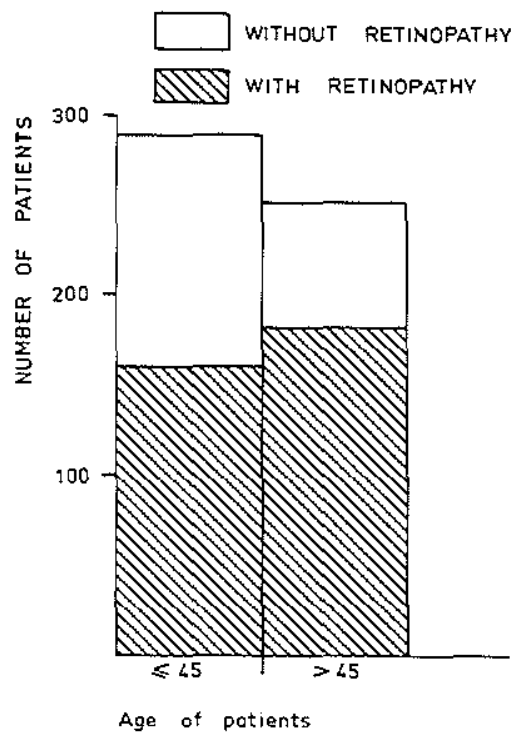

Fig. 3

Age distribution of retinopathy

TABLE III

\begin{tabular}{lcccc}
\hline Age & $\begin{array}{c}\text { With } \\
\text { retinopathy }\end{array}$ & $\begin{array}{c}\text { Without } \\
\text { retinopathy }\end{array}$ & Total & $\%$ \\
\hline$<45$ & 160 & 129 & 289 & 55.3 \\
$>45$ & 183 & 69 & 252 & 72.6 \\
\cline { 2 - 5 } Total & 343 & 198 & 541 & 63.4 \\
\hline
\end{tabular}

The distribution by age and sex was as follows: 113 of the 160 men under the age of 45 had retinopathy $(70.6 \%), 67$ of the 100 men above the age of 45 $(67.0 \%), 47$ of the 129 women under the age of $45(36.5 \%)$ and 116 of the 152 women above the age of $45(76.3 \%)$ were also affected, see Fig. 4 and Table IV.

234 of the patients included in the study were blonde, and of these $152(66 \%)$ had retinopathy. Of the 296 dark patients examined $182(63 \%)$ had retinopathy. 


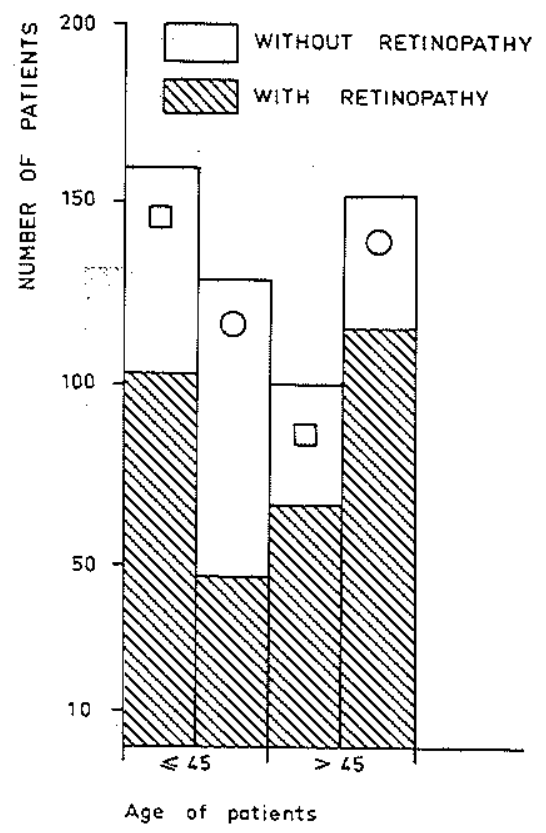

Fig. 4

Distribution of retinopathy by age and sex

TABLE IV

Age distribution of retinopathy

Females

\begin{tabular}{lcccc}
\hline Age & $\begin{array}{c}\text { With } \\
\text { retinopathy }\end{array}$ & $\begin{array}{c}\text { Without } \\
\text { retinopathy }\end{array}$ & Total & $\%$ \\
\hline$\leqslant 45$ & 47 & 82 & 129 & 36.5 \\
$>45$ & 116 & 36 & 152 & 76.3 \\
Total & 163 & 118 & 281 & 56.4 \\
\hline \multicolumn{5}{c}{ Males } \\
\hline Age & With & Without & Total & $\%$ \\
& retinopathy & retinopathy & & \\
\hline$<45$ & 113 & 47 & 160 & 70.6 \\
$>45$ & 67 & 33 & 100 & 67.0 \\
Total & 180 & 80 & 260 & 68.8 \\
\hline
\end{tabular}




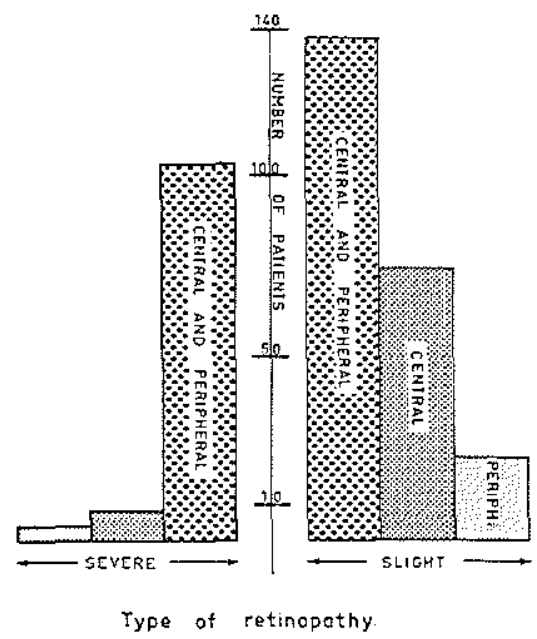

Fig. 5

Type and site of retinopathy

TABLE $V$

Type and site of retinopathy (number of patients)

\begin{tabular}{lrrr}
\hline & Severe & Slight & Total \\
\hline Peripheral & 4 & 13 & 17 \\
Central & 8 & 75 & 83 \\
Central and peripheral & 104 & 139 & 243 \\
\cline { 2 - 4 } Total & 116 & 227 & 343 \\
\hline
\end{tabular}

Type and site of retinopathy (percentages)

\begin{tabular}{lrrr}
\hline & Severe & Slight & Total \\
\hline Peripheral & 1.2 & 3.8 & 5 \\
Central & 2.3 & 21.9 & 24.2 \\
Central and peripheral & 30.3 & 40.5 & 70.8 \\
& & & 100.0
\end{tabular}


Subdivision of the patients with retinopathy by localization and severity of the retinal condition yields the following results:

peripheral retinopathy:

central retinopathy: severe, 4 patients $(1.2 \%)$;

slight, 13 patients $(3.8 \%)$;

severe, 8 patients $(2.3 \%)$;

slight, 75 patients $(21.9 \%)$;

central and peripheral retinopathy: severe, 104 patients $(30.3 \%)$;

slight, 139 patients $(40.5 \%)$.

Further subdivision according to the age and sex of the patient yields the following figures:

Slight central and peripheral retinopathy:

33 men of the 160 under the age of $45=20.6 \%$

30 men of the 100 above the age of $45=30.0 \%$

21 women of the 129 under the age of $45=16.3 \%$

55 women of the 152 above the age of $45=36.2 \%$

Severe central and peripheral retinopathy:

30 men of the 160 under the age of $45=18.8 \%$

26 men of the 100 above the age of $45=26.0 \%$

11 women of the 129 under the age of $45=8.5 \%$

37 women of the 152 above the age of $45=24.3 \%$

Slight central retinopathy:

40 men of the 160 under the age of $45=25.0 \%$

7 men of the 100 above the age of $45=7.0 \%$

9 women of the 129 under the age of $45=7.0 \%$

19 women of the 152 above the age of $45=12.5 \%$

Severe central retinopathy (no percentages as figures too small):

4 men under the age of 45

1 men above the age of 45

2 women under the age of 45

1 woman above the age of 45

Slight peripheral retinopathy (no percentages)

6 men under the age of 45

3 men above the age of 45 
3 women under the age of 45

1 woman above the age of 45

Severe peripheral retinopathy (no percentages):

0 men under the age of 45

0 men above the age of 45

1 woman under the age of 45

3 women above the age of 45 .

On the basis of psychiatric diagnosis the patients were distributed as follows:

TABLE VI

Correlation between retinopathy and psychiatric diagnosis

\begin{tabular}{lrrr}
\hline \multicolumn{1}{c}{ Diagnosis } & $\begin{array}{c}\text { without } \\
\text { retinopathy }\end{array}$ & $\begin{array}{c}\text { with } \\
\text { retinopathy }\end{array}$ & Total \\
\hline Schizophrenia & 87 & 165 & 252 \\
Hebephrenia & 8 & 7 & 15 \\
Paraphrenia & 0 & 5 & 5 \\
Catatonia & 1 & 1 & 2 \\
Paranoia & 10 & 13 & 23 \\
Alcoholic psychosis & 1 & 7 & 8 \\
Degenerative psychosis & 6 & 9 & 15 \\
Dementia paralytica & 1 & 5 & 6 \\
Exogenous psychosis & 3 & 10 & 13 \\
Epilepsy & 14 & 12 & 26 \\
Moderate mental retardation & 10 & 10 & 20 \\
Borderline of mental retardation & 26 & 43 & 69 \\
Depression & 10 & 34 & 44 \\
Mania & 5 & 4 & 9 \\
Hysteria & 3 & 8 & 11 \\
Neurosis & 1 & 3 & 4 \\
Unknown & 12 & 7 & 19 \\
& 198 & 343 & 541 \\
Total & & & \\
\hline
\end{tabular}

LOEHNER (1938), MCISAAC (1969), VANDERKAMP (1963) and LEA (1955) have described a disturbance of melanogenesis in schizophrenics. As the phenothiazines also affect the melanogenesis, we examined our material to see if retinopathy was relatively more frequently seen in schizophrenics than in the other patients. 
TABLE VII

Retinopathy in schizophrenic group

\begin{tabular}{lccc}
\hline \multicolumn{1}{c}{ Diagnosis } & $\begin{array}{c}\text { Without } \\
\text { retinopathy }\end{array}$ & $\begin{array}{c}\text { With } \\
\text { retinopathy }\end{array}$ & Total \\
\hline Schizophrenic group & 106 & 191 & 297 \\
Others & 92 & 152 & 244 \\
\cline { 2 - 4 } Total & 198 & 343 & 541 \\
\hline
\end{tabular}

Expressed in percentages, retinopathy was found in $64.3 \%$ of the patients in the schizophrenic group and $62.3 \%$ of the other patients. There was thus no significant difference in the incidence of retinopathy in the two groups.

In order to determine the effect of the phenothiazine treatment on the incidence of retinopathy the statisticians subdivided the patient material into groups. The relationship between the total dose of phenothiazine preparations taken and the retinopathy is as follows:

TABLE VIM

Retinopathy and total dose of phenothiazine preparations

\begin{tabular}{cccc}
\hline $\begin{array}{c}\text { Total dose } \\
\text { in grammes }\end{array}$ & Retinopathy & No retinopathy & Total \\
\hline$<50$ & & & \\
$50-149$ & 86 & 77 & 163 \\
$150-349$ & 75 & 45 & 120 \\
$350-749$ & 78 & 34 & 102 \\
$>750$ & 77 & 35 & 102 \\
& 47 & 7 & 54 \\
\hline
\end{tabular}

The percentage of retinopathy is different in the various groups: the correlation between the incidence of retinopathy and the total dose of phenothiazine preparations is highly significant $\left(\chi^{2}=21.69, P=0.0002\right)$. See also Fig. 6 .

The relationship between the average daily dose of phenothiazine preparations and the retinopathy is as follows: 
TABLE $\mathbf{X}$

Retinopathy and average daily dose of phenothiazine preparations

\begin{tabular}{cccr}
\hline $\begin{array}{c}\text { Daily dose } \\
\text { in mg }\end{array}$ & Retinopathy & No retinopathy & Total \\
\hline$<40$ & 40 & 34 & 74 \\
$40-99$ & 82 & 56 & 138 \\
$100-189$ & 93 & 56 & 149 \\
$>190$ & 128 & 52 & 180 \\
\hline
\end{tabular}
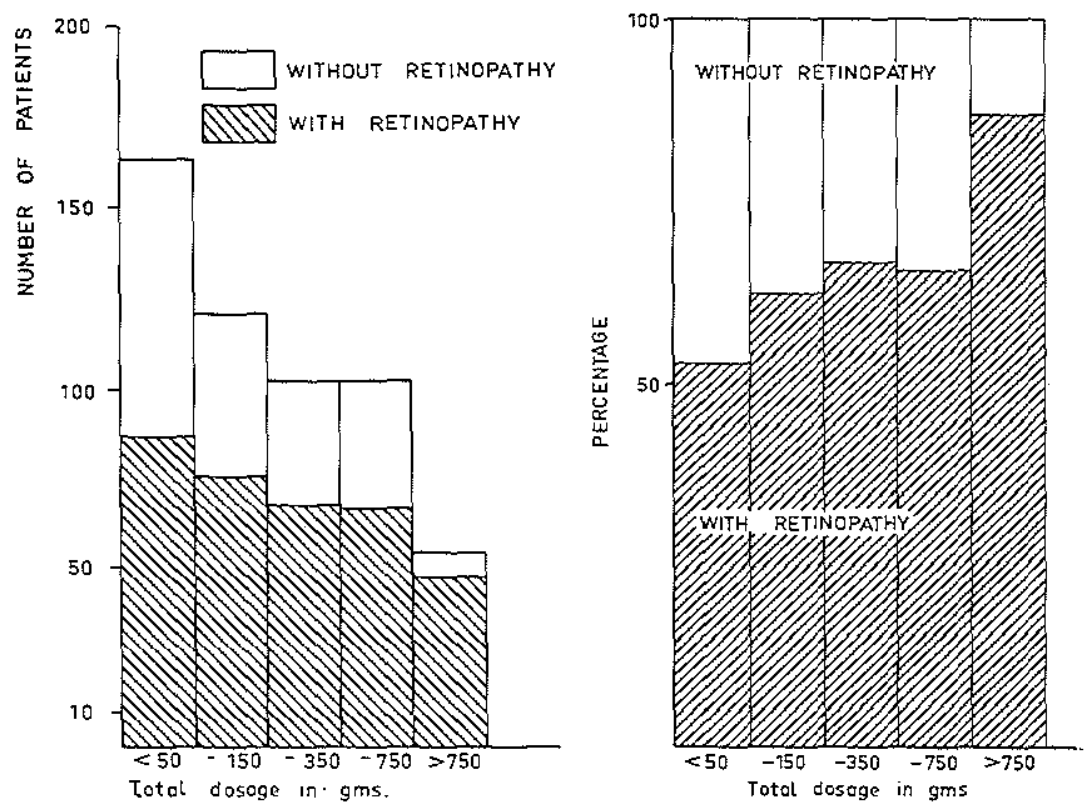

Fig. 6

Relationship between retinopathy and total dose in grammes

a) number of patients

b) in percentages

The percentage of retinopathy is different in the various groups and increases. significantly as the average daily dose increases. $\left(\chi^{2}=8.40, P=0.04\right)$. See also Fig. 7.

The relationship between the duration of the phenothiazine treatment and the: 


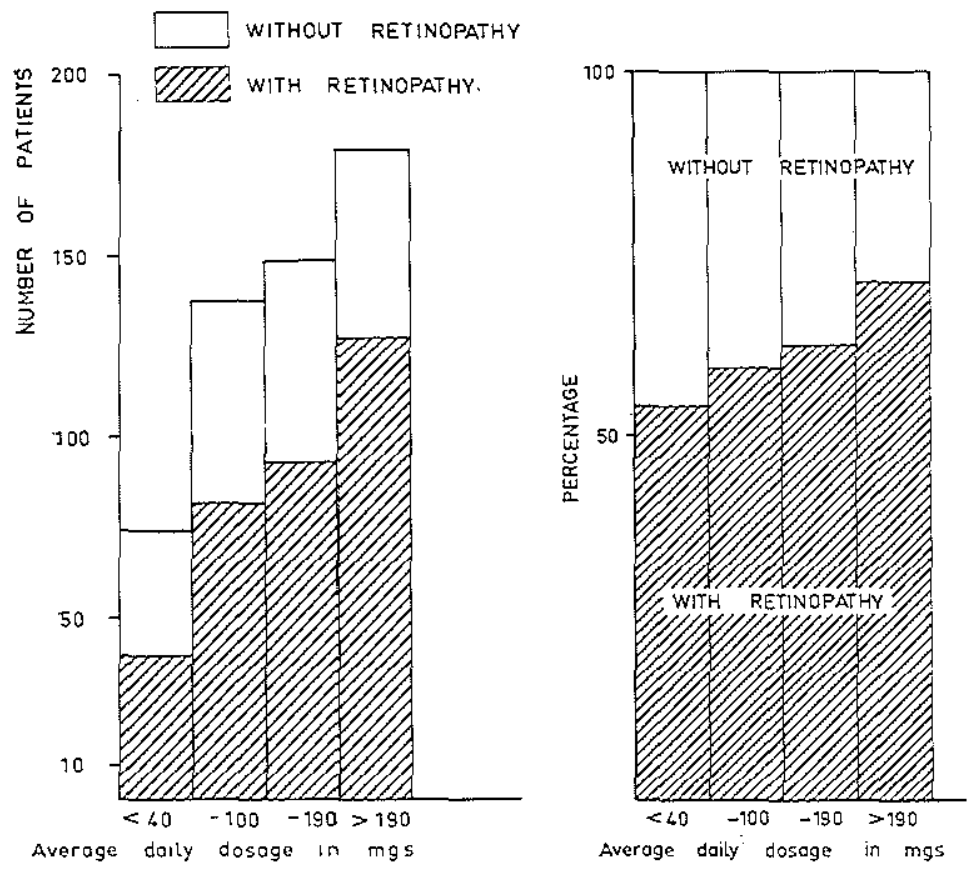

Fig. 7

Relationship between retinopathy and average daily dose in $\mathrm{mg}$

a) number of patients

b) in percentages

retinopathy is as follows:

TABLE $x$

Retinopathy and duration of phenothiazine treatment

\begin{tabular}{cccc}
\hline $\begin{array}{l}\text { Duration of } \\
\text { treatment } \\
\text { in months }\end{array}$ & Retinopathy & No retinopathy & Total \\
\hline$<10$ & 40 & 38 & 78 \\
$10-19$ & 46 & 42 & 88 \\
$20-39$ & 66 & 40 & 106 \\
$40-89$ & 113 & 43 & 156 \\
$>90$ & 78 & 35 & 113 \\
\hline
\end{tabular}



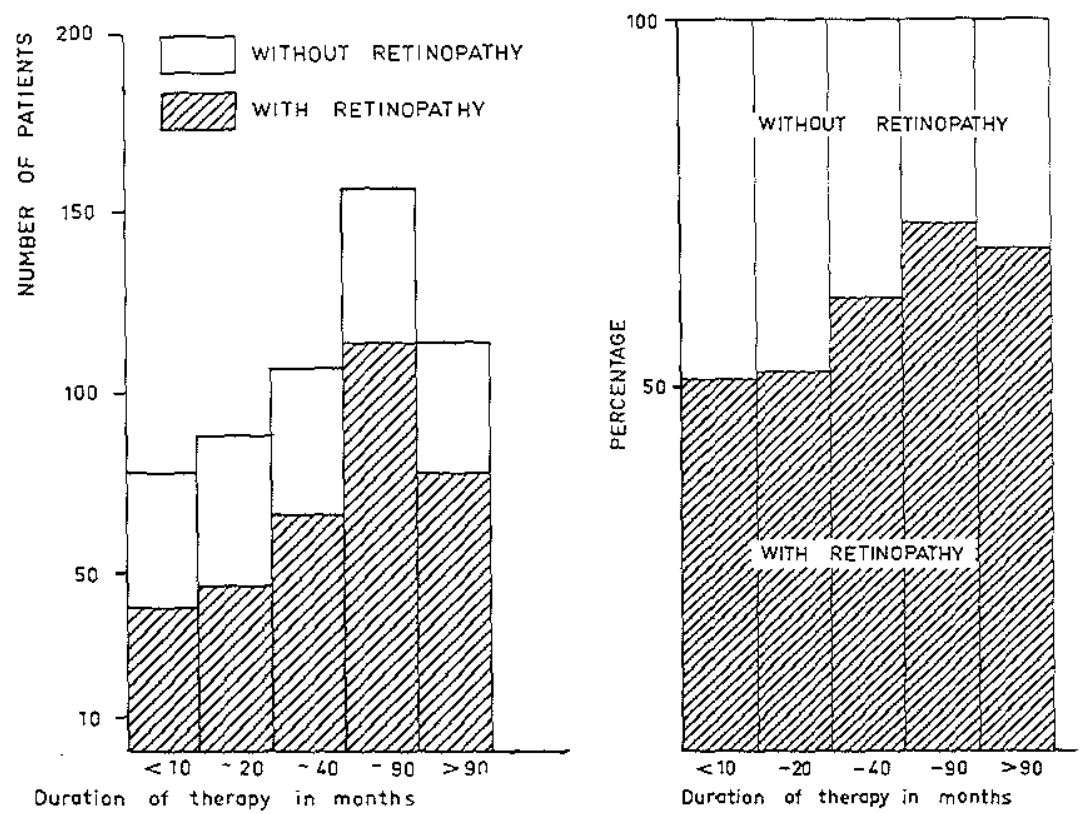

Fig. 8

Relationship between retinopathy and duration of treatment

a) number of patients

b) in percentages

The percentage of retinopathy is different in the various groups and shows a highly significant increase as the duration of the treatment increases. $\left(\chi^{2}=16.72\right.$, $P=0.002$ ). See also Fig. 8 .

If these data are tested by Kendall"s rank correlation technique with paired replicates the conclusions are the same: there is a highly significant rise in the probability of retinopathy as the dose of phenothiazine preparations which the patient has taken becomes higher and as the duration of treatment becomes longer.

\section{Visual acuity}

408 patients had normal visual acuity in both eyes, i.e. $10 / 10$ with or without correction of refractive errors. 160 of these patients ( 320 eyes) had no retinopathy and 248 (496 eyes) had retinopathy. 17 patients without retinopathy had normal visual acuity in one eye (10 right eyes and 7 left eyes). 45 patients with 
retinopathy had normal visual acuity in one eye ( 25 right eyes and 20 left eyes). Visual acuity of less than 10/10 was found in 59 eyes without retinopathy and in 145 eyes with retinopathy. To summarize:

TABLE XY

Visual acuity

\begin{tabular}{lccr}
\hline & $\begin{array}{c}\text { Eyes with visual acuity } \\
\text { less than 10/10 }\end{array}$ & $\begin{array}{c}\text { Eyes with } \\
\text { normal vision }\end{array}$ & Tota \\
\hline With retinopathy & 145 & 541 & 686 \\
Without retinopathy & 59 & 337 & 396 \\
Total & 204 & 878 & 1.082 \\
\hline
\end{tabular}

Visual acuity less than $10 / 10$ was found in $21.1 \%$ of the group with retinopathy and in $14.9 \%$ of the group without retinopathy. For all the patients included in this study the figure is $18.9 \%$ with visual acuity less than $10 / 10$.

$71.1 \%$ of the patients with poor visual acuity had retinopathy and $28.9 \%$ had no retinopathy. $61.6 \%$ of the patients with normal visual acuity had a retinopathy and $38.4 \%$ no retinopathy.

\section{Colour vision}

Lack of co-operation on the part of the patients made it impossible to perform colour tests on 14 men and 45 women. Colour defects of various types were found in 17 men. i.e. $6.9 \%$ of the 246 men investigated. Eight of these were protans. seven deutans and two unclassified. None of the women had colour defects.

Classification of the 17 men with colour defects by the degree of retinopathy yields the following results:

TABLE XII

Colour defects

\begin{tabular}{lcccc}
\hline Colour defect & Normal retina & $\begin{array}{c}\text { Slight } \\
\text { retinopathy }\end{array}$ & $\begin{array}{c}\text { Severe } \\
\text { retinopathy }\end{array}$ & Total \\
\hline Protans & 1 & 6 & 1 & 8 \\
Deutans & 0 & 5 & 2 & 7 \\
Unclassified & 0 & 2 & 0 & 2 \\
\cline { 2 - 5 } Total & 1 & 13 & 3 & 17 \\
\hline
\end{tabular}




\section{Electro-oculogram}

An EOG investigation was attempted on a number of patients and the results in 93 cases were considered to be reliable. In order to get better insight into the results obtained, the investigation was also carried out on a group of 23 normal subjects of approximately the same age as the patients. These results appear in the table below as "Control Group".

At the time of this study $185 \%$ * was considered to be the lower limit of normal for the LP/DT ratio, with a standard deviation of $20 \%$. The results can thus be divided into three groups:

1. Normal EOG with LP/DT ratio $\geqslant 205 \%$ :

2. Doubtful:

a) probably normal EOG with LP/DT ratio of $185-205 \%$

b) probably subnormal EOG with LP/DT ratio of $165-185 \%$;

3. Subnormal EOG with LP/DT ratio $\leqslant 165 \%$.

TABLE XIII

Results of EOG investigation (figures represent number of eyes)

\begin{tabular}{|c|c|c|c|c|}
\hline \multirow{2}{*}{$\begin{array}{c}\text { LP/DT ratio } \\
\%\end{array}$} & \multirow{2}{*}{$\begin{array}{l}\text { Control } \\
\text { group }\end{array}$} & \multicolumn{3}{|c|}{ Phenothiazine group } \\
\hline & & $\begin{array}{l}\text { No } \\
\text { retinopathy }\end{array}$ & $\begin{array}{l}\text { Slight } \\
\text { retinopathy }\end{array}$ & $\begin{array}{c}\text { Severe } \\
\text { retinopathy }\end{array}$ \\
\hline$\leqslant 165$ & 2 & 7 & 23 & 11 \\
\hline $165-205$ & 18 & 19 & 54 & 9 \\
\hline$\geqslant 205$ & 26 & 16 & 35 & 12 \\
\hline Total & 46 & 42 & 112 & 32 \\
\hline
\end{tabular}

The percentage of pathological EOG's in the control group is $4.3 \%$. in the phenothiazine group without visible anomalies $16.7 \%$. in the group with slight retinopathy $20.5 \%$ and in the group with severe retinopathy $34.4 \%$. See also Fig. 9.

* $165 \%$ is now the accepted ratio (1969, VAN LITH \& BALIK, to be published). 


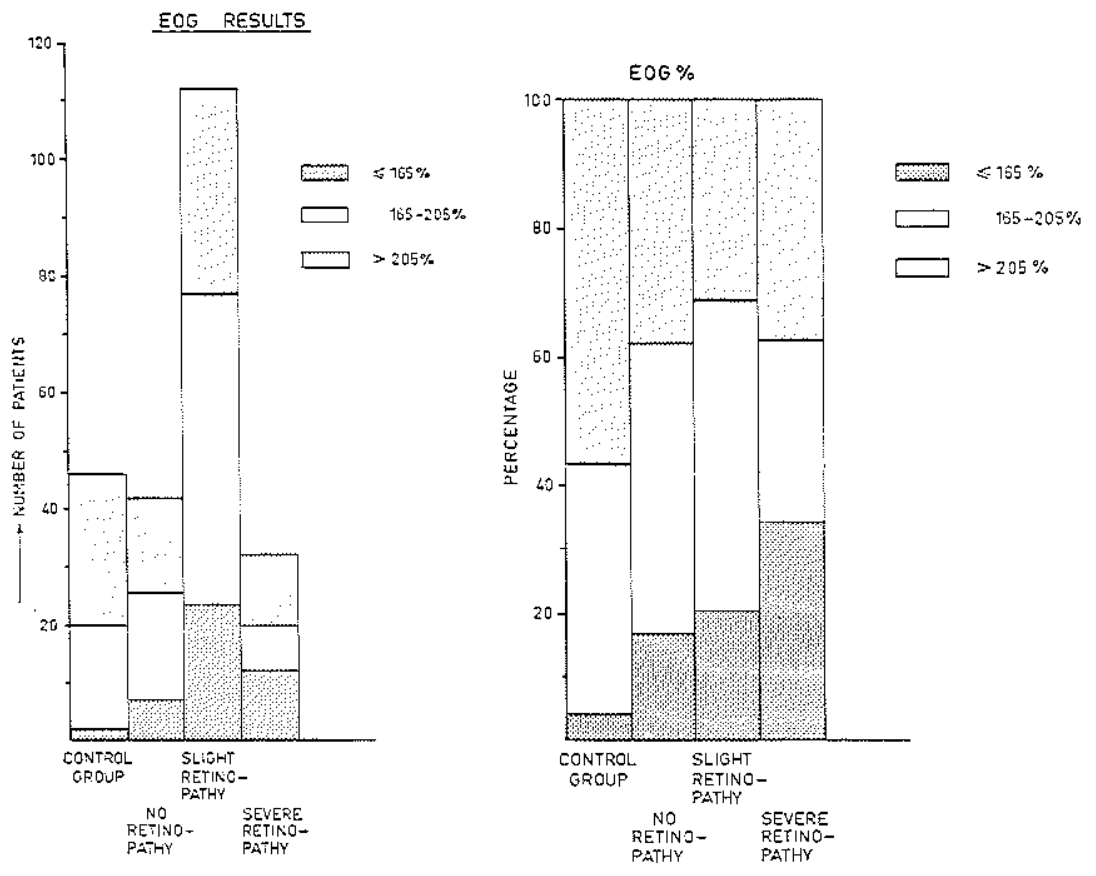

Fig. 9

EOG results

a) number of patients

b) in percentages

Comparison of the phenothiazine group with the control group shows that the percentage of pathological EOG's is significantly higher in the former group $\left(\gamma^{2}=13.6, P=0.01\right)$.

\section{DISCUSSION}

Before considering the results in detail, some explanation is necessary of the way in which the total dose and the average daily dose of the phenothiazine preparations have been calculated. These figures were arrived at by simply adding up the amounts of the different phenothiazine preparations in grammes which the patient had taken.

The most ideal situation would be if a patient had only taken one pheno- 
thiazine preparation. In our complete patient material this was only the case seven times. The other patients had all been given a combination of preparations or the preparation prescribed had been changed in the course of treatment.

If one considers the phenothiazine preparations which are included in this study, they can be roughly divided into preparations which are given in high dosage and those which are given in low dosage. For each preparation there is a minimum dose which is still just therapeutically active. It would be possible to call this dose $\mathrm{K}$ and to express, for each preparation, the amount which had been taken in this factor K. It is, however, extremely difficult to decide upon the value of $\mathrm{K}$ for each preparation: for example, the average daily dosage of promazine suggested by GOODMAN \& GILMAN is $500-1,000 \mathrm{mg}$., by krelHOLZ 100-600 mg.; for chlorpromazine, GOODMAN \& GILMAN 300-800 mg., KIELkOLZZ 75-500 mg. Furthermore, there are objections to equating the pharmacodynamic action of different drugs, as it is known that the active components of various preparations have different points of action in the organism. In addition, it was not our intention in this study to compare the pharmacological and pharmacodynamic actions of the various phenothiazine preparations on the psyche, but to estimate their retinotoxicity. Although arguments can undoubtedly be advanced against simply adding up the amounts of phenothiazine preparations taken per patient, the advantages of a simple procedure seem to us to be evident.

\section{Skin pigmentations}

These were only observed in female patients $(0.9 \%)$. Originally it was thought that the slate-blue discoloration was only found in women, possibly because of hormonal influence (GREINER \& BERRY, 1964). Later, however, it appeared that male patients could also be affected (BAN \& LEHMANN, 1965). These authors found fifteen cases of skin pigmentation among 1,500 patients $(1 \%)$ and called this phenomenon 'a rare side-effect of chlorpromazine'. According to RIVES \& PELLERAT (1966), skin pigmentations occur in less than $1 \%$.

The discoloration is caused by melanin-containing cells in the deeper layers of the stratum spinosum, stratum basalis and corium (GUNBY, 1966). HASHIMOTO (1966) found an increased number of melanin granules and round or bizarreshaped bodies in the lysosomes of the large phagocytes of the dermis as well as of the endothelial and perithelial cells of the dermal blood vessels". ZELICKSON $(1964,1965,1966)$ calls these dense bodies 'drug metabolite' consisting of pseudomelanin or some other form of pigment. 
PERRY, CULLING, BERRY \& HANSEN (1964) consider that ultraviolet light causes the production of a toxic compound from a 7-hydroxylated chlorpromazine derivative in the skin, cornea and lens, which is responsible for the increased melanin production. They were able to isolate 7-hydroxychlorpromazine from the liver and urine of patients who had been treated with large doses of chlorpromazine for long periods of time. They observed that 7-hydroxychlorpromazine rapidly turned purple both in solution and on paper chromatograms after brief exposure to sunlight and wondered if this metabolite might be responsible for the photosensitive purplish pigmentation of the skin.

SATANOVE $(1965,1967)$ with his "skin window' technique, saw the transportation of pigment to the blood vessels by leucocytes and macrophages.

\section{Cornea and lens}

As we unfortunately had no hand slit-lamp, only a few patients were able to undergo slit-lamp examination. When this was essential the patients had to be transported to one of the Eye Hospitals, which made extra work for the nursing staff.

This will be the reason why such a small number of corneal $(1.5 \%)$ and lens $(8.5 \%$ ) opacities were found; only the most pronounced lens opacities could be seen with transmitted light without a slit-lamp. In the literature, however, the findings vary greatly: from $0 \%$ (SARIN et al., 1966) to $85.1 \%$ (SANDVIG, 1965).

In our material opacities of the lens and cornea were found by a total dosage of phenothiazine preparations lower than $500 \mathrm{gm}$., which is not in agreement with the findings of DELONG et al. (1965). No conclusion could be drawn about any influence of the total dosage, average daily dose or duration of the treatment on the incidence of corneal and lens opacities (see Table 2).

Of the eight cases with corneal anomalies one had no lens opacities, the other seven cases had both lens and corneal opacities.

Concerning the nature of these opacities, NOURI \& CUENDET (1968) have suggested that they are formed of iris pigment. They punctured the anterior chamber of a patient with corneal and lens anomalies and found iris pigment in the aspirated aqueous.

In addition, the situation of the opacities suggests pigment: pigment in the anterior chamber is usually precipitated in the pupil space (ADLER, 1965). On the other hand, NORDMANN (personal communication, 1969) maintains that iris pigment in only found on the lens capsule, not in the capsule or lens. 
The only publication in which opacities in the posterior capsule of the lens due to phenothiazine preparations are mentioned is that of MCDONALD (1967). His observations were, however, on guinea pigs: opacities at the back of the lens in man have not been described.

KASSMAN (1967) has drawn attention to the resemblance between the phenothiazine cataract and Vogt's 'Sonnenblumenstar" which occurs in Wilson's disease and in the presence of an intra-ocular foreign body containing copper. The skin pigmentations and extra-pyramidal signs occurring during phenothiazine treatment also resemble those seen in Wilson's disease (Annotation Lancet 1965).

\section{Intra-ocular pressure}

The atropine-like action of the phenothiazines tends to cause a dilated pupil, so that in elderly patients with a narrow chamber angle there is an increased chance of glaucoma. In the small proportion of cases in which the intra-ocular pressure was measured, however, no harmful influence of the phenothiazines on the pressure could be observed.

\section{Retinopathy}

The term "retinopathy" is not defined in the majority of text-books. The following definition seems to be acceptable: retinopathy is a condition of the retina in which the anatomy and/or physiology is abnormal, with the exception of hereditary conditions (dystrophy) and inflammatory conditions.

The retinal anomalies found in patients treated with phenothiazine preparations fall under this definition and one may therefore speak of a phenothiazine retinopathy.

The number of retinopathy cases found in our patient material is high $(63.4 \%)$ compared with the percentages in the literature:

$\begin{array}{lc}\text { APPELBAUM } & 0 \text { in } 70 \text { patients } \\ \text { BARSA } & 0 \text { in } 658 \text { patients } \\ \text { BAUMANN } & 2 \text { in } 35 \text { patients } \\ \text { DELONG } & 0 \text { in } 131 \text { patients } \\ \text { EDLER } & 14 \text { in } 261 \text { patients } \\ \text { GOAR } & 28 \text { in } 34 \text { patients } \\ \text { HAGOPIAN } & 8 \text { in } 164 \text { patients }\end{array}$




$\begin{array}{lr}\text { RINTELEN } & 24 \text { in } 62 \text { patients } \\ \text { SARIN } & 0 \text { in } 34 \text { patients } \\ \text { SIDDALL } & 15 \text { in } 50 \text { patients } \\ \text { VERREY } & 24 \text { in } 78 \text { patients } \\ \text { WEEKLEY } & 4 \text { in } 29 \text { patients }\end{array}$

The majority of authors, however, have regarded clumping of pigment and marked depigmentations as the criteria for retinopathy; only SIDDALL (1965) speaks of "granularity of pigment".

In our study coarsening of the pigment pattern of the retina was taken as the criterion for retinopathy.

Retinopathy is found in our patient material in approximately the same percentage in men above and below 45 years of age and in women above the age of $45(67.0 \%, 70.6 \%, 76.3 \%)$. In the group of women below the age of 45 , however, retinopathy was found in only $36.5 \%$. Possible explanations of this could be that the patients had, on the average, been given a lower dosage of phenothiazine preparations or that the duration of the treatment had been shorter. Neither of these possibilities, however, could be established as the explanation of the low percentage of retinopathy in women under the age of 45 .

Both in the group where the retinopathy was called "slight" and in the "severe" retinopathy group the condition was seen most frequently affecting the whole fundus (central + peripheral) (Fig. 3 and Table 5). From the data on the localization of the retinopathy and the age and sex of the patient no conclusions can be drawn.

POTTS, WEST \& SHEARER (1959) using various monochromatic filters in the television ophthalmoscope, were able to show that the pigmentations in retinopathy lie deep in the retina.

Using panchromatic film material, CRAANDIJK \& AAN DE KERK (1969) were able to photograph lesions in the deeper layers of the retina. This technique was also used on one of our patients with retinopathy of the macula. The photograph made with orthochromatic film shows a slight degree of retinopathy, whereas the photograph with panchromatic film shows that a much larger area is affected. (See photographs).

For information about the nature of the retinopathy we are as yet dependent on animal experiments: post-mortem examination of a human eye has not been performed. This would be desirable in order to supplement our knowledge of the condition. 
Extensive experiments performed by CERLETTI \& MEIER-RUGE (1967) and POTTS (1962) on cats, rabbits and hamsters have shown that some phenothiazine derivatives are absorbed selectively on the melanin of the choroid, with resultant severe disorganization of the function of the choriocapillaris. This leads to degeneration of the distal segment of the rods and the formation of lipoid in the pigment epithelium. Later the cones are also affected.

The toxic action of phenothiazine derivatives on the human eye may be different from the effect on the cat. Among our patients cases were seen in which the retinopathy affected the macula only, where cones form the majority of photoreceptors.

\section{Visual acuity}

In our codification scheme patients with visual acuity less than $10 / 10$ were also given a number for the cause of the anomaly: corneal lesions, opacities in lens or vitreous, lesions of the optic nerve and retinal lesions other than phenothiazine retinopathy. If none of these anomalies could be found the poor vision was coded under a separate number: poor vision of unknown origin. Retinopathy was not assumed to be a cause of poor visual acuity. A difficulty was that the determination of the refraction in some patients was very difficult owing to lack of cooperation.

This group of poor vision without an obvious cause comprised 84 eyes: 21 of these $(25 \%)$ had no retinopathy, $28(33.3 \%)$ had slight retinopathy and 35 $(47.7 \%)$ had severe retinopathy.

The incidence of retinopathy in the whole patient material is: $396(36.6 \%)$ without retinopathy, $454(42 \%)$ with slight retinopathy and $232(21.4 \%)$ with severe retinopathy. Comparison of the two groups shows a distinct shift in the group of poor vision of unknown origin towards severe retinopathy.

It would thus appear possible that retinopathy may cause deterioration of vision. A definite conclusion, however, cannot be drawn from our material as there are so many uncertain factors in the determination of the visual acuity, especially in psychiatric patients.

\section{Colour defects}

WAARDENBURG's (1963) figure for the incidence of colour defects in men is $6.58-9.0 \%$. The incidence in our material, $6.9 \%$ is in good agreement with this figure. 
According to WAARDENBURG the incidence of protans varies between $0.95 \%$ and $2.54 \%$ and the incidence of deutans between $5.08 \%$ and $6.80 \%$. In our material, however, we found $3.3 \%$ protans. $2.8 \%$ deutans and $0.8 \%$ unclassified. Seven of the eight protans had retinopathy. It seems probable that the phenothiazine intoxication plays an important part in the explanation of the occurrence of these colour defects.

\section{Electro-oculogram}

The electro-oculogram provides information about the quality of the choriocapillaris, the pigment epithelium, Bruch's membrane and the retinal rods and cones. The results of the EOG investigation of patients taking phenothiazine preparations show that these tissues are unfavourably influenced by these drugs. It also appears that, as the retinopathy becomes more severe, the LP/DT ratio shifts further towards pathological values*.

TABLE XIV

EOG results in percentages

\begin{tabular}{|c|c|c|c|c|c|}
\hline \multirow{2}{*}{$\begin{array}{c}\text { LP/DT ratio } \\
\%\end{array}$} & \multirow[t]{2}{*}{ Control group } & \multicolumn{3}{|c|}{ Phenothiazine group } & \multirow{2}{*}{$\begin{array}{l}\text { Phenothiazine } \\
\text { group (total) }\end{array}$} \\
\hline & & $\begin{array}{c}\text { No } \\
\text { retino- } \\
\text { pathy }\end{array}$ & $\begin{array}{l}\text { Slight } \\
\text { retino- } \\
\text { pathy }\end{array}$ & $\begin{array}{l}\text { Severe } \\
\text { retino- } \\
\text { pathy }\end{array}$ & \\
\hline$\leqslant 165$ & 4.3 & 16.7 & 20.5 & 34.4 & 22.0 \\
\hline $165-205$ & 39.1 & 45.2 & 48.2 & 28.1 & 44.1 \\
\hline$>205$ & 56.6 & 38.1 & 31.3 & 37.5 & 33.9 \\
\hline
\end{tabular}

The results obtained by MATHALONE (1967) who only gives one EOG value per patient, also point in the same direction. His results are given here, rearranged into groups as above.

TABLE XV

\begin{tabular}{lr}
\multicolumn{2}{c}{ EOG results (Mathalone) } \\
\hline$<165 \%$ & 3 \\
$165-205 \%$ & 6 \\
$\geqslant 205 \%$ & 3 \\
Total & $\frac{3}{12}$
\end{tabular}

* HENKES $(1967,1968)$ reported on a small group of these patients. 


\section{Fluorescein angiography}

One clear case of phenothiazine retinopathy was examined after $5 \mathrm{cc} .10 \%$ fluorescein solution had been injected into the antecubital vein. A modified Zeiss camera was used (Arend-van Gogh electronic flash unit and chronograph). A Schott filter GG14 was used at the film plane and a Baird Atomic B4 interference filter before the electronic flash: the film was Ilford FP-3 (technique described by CRAANDIJK, 1968). No abnormalities were seen in the photographs.

KRILL, NEWELL \& CHISHTI (1968) performed fluorescein angiography on a 41-year-old patient with phenothiazine retinopathy following thioridazine treatment. The daily dosage had been $1,600 \mathrm{mg}$. for $11 / 2$ months followed by $600 \mathrm{mg}$. for two weeks. The treatment was then stopped because the patient complained of poor vision.

After the fluorescein had been injected $(10 \mathrm{cc} .5 \%$ solution) the choroidal vessels were seen to be narrower than before the injection. Fluorescence was also seen at the posterior pole of the eye, which showed variations in intensity. This diffuse fluorescence became more uniform in brightness and easier to see by the late venous phase.

These very different results may possibly be due to the use of different filters. but are probably dependent upon the severity of the pigment changes. Our patient showed coarsening of the pigment pattern only, whereas Krill's patient had pigment clumps of various sizes and larger coalescent pigment plaques having the appearance of naevi".

\section{DIFFERENTIAC DIAGNOSIS}

1. Other iatrogenic retinopathies.

a. Retinopathy caused by chloroquine and hydroxy-chloroquine. Here also coarsening of the pigment pattern of the fundus is seen. In severe cases the optic discs are pale, the blood vessels are narrow and the so-called 'bull's eye fundus is seen. The case history is important.

b. Secondary pigmentary degeneration after smallpox vaccination. This retinopathy is restricted to the periphery and the pigment pattern is coarser.

c. Retinopathy caused by atoxyl, optochine, eucupine, septojod. These drugs are no longer used (see pp. 13-17). 
2. Infectious retinopathies:

a. Congenital syphilis. The pepper-and-salt fundus is usually peripheral.

b. Secondary syphilis. The pigment pattern is usually coarser.

c. Secondary pigmentary degeneration following rubella. This is, as l.b. restricted to the periphery.

d. Secondary pigmentary degeneration after measles.

e. Retinopathy in Behçet's disease (this disease is considered by some authorities to be an infection by an unknown agent).

f. Pigmented scars in the retina in Toxoplasmosis. These are usually much coarser.

g. Retinopathy following typhoid fever.

3. Senile pigmentary changes and changes due to arteriosclerosis and arteriolosclerosis. These are usually peripheral but are also found in the central area. They are usually not seen under the age of 45 years.

4. Tapeto-retinal degeneration ("retinitis pigmentosa"). The typical "bone corpuscle' structure seen in the peripheral form of this disease is not seen in phenothiazine retinopathy.

\section{THERAPY}

The lightening effect of d-penicillamine on the skin pigmentations caused by phenothiazines has been described by Nicolson et al. (1966). This substance is also reported to have a favourable influence on the patient's psychiatric condition.

These observations led us to investigate the effect of d-penicillamine* on the retinal pigmentations. Five women and four men with marked retinopathy were treated with $900 \mathrm{mg}$. d-penicillamine per day for four periods of six days. On the seventh day they were given $2 \times 30 \mathrm{ml}$. of a mineral "cocktail" consisting of:

$\begin{array}{llc}\mathrm{FeSO}_{4} \cdot 7 \mathrm{H}_{2} \mathrm{O} & 1.0 \text { gr. in } 1 \text { litre aq. dest. } \\ \mathrm{MgCl}_{2} .7 \mathrm{H}_{2} \mathrm{O} & 0.5 \text { gr. } & - \text { do - } \\ \mathrm{Co}\left(\mathrm{NO}_{3}\right)_{2} \cdot 6 \mathrm{H}_{2} \mathrm{O} & 0.2 \mathrm{gr} . & - \text { do - } \\ \mathrm{ZnSO}_{4} .7 \mathrm{H}_{2} \mathrm{O} & 0.2 \text { gr. } & - \text { do - } \\ \mathrm{MnSO}_{4} .7 \mathrm{H}_{2} \mathrm{O} & 0.2 \text { gr. } & - \text { do - }\end{array}$

The patients were given a copper-free diet.

* provided by Mycofarm Delft (Koninklijke Nederlandsche Gist- en Spiritusfabriek N.V.) 
Before the experiment was started fundus photographs and EOG's were made, the latter was only successful in three cases. A month later the fundus photographs and EOG's were repeated. The nursing and medical staff were asked to observe the patients carefully during this month. This experiment was carried out in the winter in order to reduce the effect of sunlight as far as possible.

\section{Results}

The fundus photographs were unchanged, the EOG's had not improved and the patients' behaviour was unaltered in the month of treatment.

The duration of the experiment may have been too short. MATHALONE (1967) also working with d-penicillamine, extended the experiment over eight months. Some improvement was seen in three patients with corneal opacities from the group of ten patients treated.

\section{CONCLUSIONS}

From this study it appears that the administration of phenothiazine derivatives to psychiatric patients, varying in age from 17 to 81 years, gives rise to:

a. Discoloration of the skin, where it is exposed to the sun, in $0.9 \%$ of cases. These were all women.

b. Photosensitivity in $9.1 \%$ of cases. This phenomenon was observed equally in men and women.

c. Corneal opacities in the form of fine yellowish-white granules in the stroma and Descemet's membrane and in and on the endothelium.

d. Lens opacities, granular, on and in the anterior capsule of the lens.

e. Retinopathy in the form of coarsening of the pattern of the pigment epithelium. This was seen in $63.4 \%$ of cases. In women under 45 years of age the percentage was lower $(36.5 \%)$; no explanation could be found for this.

It was impossible to ascribe a more pronounced retinotoxic action to one or more specific phenothiazine preparations, because nearly all the patients had been treated with more than one preparation.

Severe retinopathy usually affects the whole retina. Increase in the total dose of phenothiazine preparations taken leads to a highly significant rise in the incidence of retinopathy. The probability of retinopathy increases significantly as the average daily dosage becomes larger. There is a highly signi- 
ficant rise in the probability of retinopathy as the duration of the treatment becomes longer.

f. Possibly deterioration of vision.

g. An abnormally high proportion of protans in the group of patients with colour defects.

h. Disturbance of the standing potential of the eye. The LP/DT ratio of the EOG shifts significantly towards pathological values.

The significance of the EOG, as an early diagnostic aid for the detection of an incipient retinopathy during phenothiazine treatment, has not yet been definitely established, but it is certainly of value as a supplementary aid.

In this study serious defects in the visual function of patients treated with phenothazine preparations were not found. The occurrence of a retinopathy, however, which becomes more severe when the drugs are administered in higher dosage or for a longer period of time, suggests that caution is indicated. As long as there are no rew therapeutic measures, it is possible that these patients will continue to take phenothiazine derivatives for many years, so that an investigation over a longer period of time, partly in the form of a follow-up of the present material. would be a sensible procedure.

SUMMARY

Publications about the retinotoxic action of phenothiazine derivatives led the author to undertake an ophthalmological investigation in two psychiatric hospitals in The Netherlands.

The pharmacological actions of phenothiazine preparations are listed and a survey of the phenothiazine derivatives which are at present in use is given.

Some retinotoxic substances are discussed and a survey is given of the literature on the ocular complications of phenothiazine therapy.

The eyes of 561 patients were examined, of whom 541 are included in this study. 343 of these patients $(63.4 \%)$ were found to have retinopathy. The correlation between the retinopathy and the total dose of phenothiazine preparations taken, and between the retinopathy and the duration of treatment, was highly significant. The correlation between the retinopathy and the average daily dose taken was significant.

The retinopathy was associated with a reduced standing potential of the eye, as determined by electro-oculography. It was possibly responsible for diminished 
visual acuity in some cases, and for an abnormally large proportion of protans in the group of patients with colour defects.

It was not possible to ascribe a more severe retinotoxic action to one or more specific phenothiazine derivatives than to others.

In the author's opinion regular examination of the eyes of patients who are being treated with phenothiazine preparations in high dosage and/or for a long period of time is indicated.

RÉSUMÉ

Après avoir pris connaissance de l'effet rétinotoxique des dérivés de la phénothiazine. l'auteur a entrepris des recherches dans deux hôpitaux psychiatriques des Pays Bas.

L'action pharmacologique des préparations de phénothiazine est rappelée et les dérivés actuellement utilisés sont passés en revue.

Quelques substances rétinotoxiques sont discutées et la littérature concernant les complications oculaires observées au cours de traitements à la phénothiazine est commentée.

Les yeux de 561 patients ont été examinés. 541 d'entre eux entrent dans cette étude. Chez 343 de ces malades $(63,4 \%)$ on a observé une rétinopathie. Les corrélations entre la rétinopathie d"une part, la dose totale de phénothiazine ou la durée du traitement d'autre part, étaient hautement significatives. La corrélation entre la rétinopathie et la dose moyenne journalière était significative.

La rétinopathie est associée à une réduction du potentiel continu (standing potential) qui est déterminé par l'électro-oculographie. Elle était peut-être aussi responsable de la diminution de l'acuité visuelle constatée dans un certain nombre de cas, et de la proportion anormalement élevée de protanopes dans le groupe de malades atteints danomalies du sens chromatique.

Il était impossible d’attribuer à certains dérivés de la phenothiazine un effet rétinotoxique plus fort qu“à d’autres.

Un examen oculistique régulier de malades qui emploient des préparations de phenothiazine pendant un temps plus long et/ou en grandes doses, a été indiqué d’après lauteur. 


\section{ZUSAMMENFASSUNG}

Nach Kenntnisnahme der Veröffentlichungen über den retinotoxischen Einfluß der Phenothiazinderivate hat der Verfasser eine Untersuchungsreihe in zwei psychiatrischen Kliniken der Niederlande unternommen.

Die pharmakologischen Eigenschaften von Phenothiazinpräparaten werden aufgezählt und die heute gebräuchlichen Phenothiazinderivate im Einzelnen besprochen.

Einige retinotoxische Substanzen werden diskutiert und es wird üter die am Auge beobachteten Komplikationen der Phenothiazintherapie referiert.

Die Augen von 561 Patienten wurden untersucht. 541 davon wurden in dieser Reihe berücksichtigt. Bei 343 von diesen Patienten (63.4\%) wurde eine Retinopathie festgestellt. Die Korrelationen zwischen der Retinopathie einerseits, der Gesamtdosis des verabreichten Phenothiazins oder der Behandlungsdauer andererseits waren in hohem Maße signifikant. Die Korrelation zwischen Retinopathie und mittlerer Tagesdosis war signifikant.

Die Retinopathie ist mit einer Herabsetzung des elektro-okulographisch gemessenen Ruhepotentials (standing potential) verbunden. Sie ist möglicherweise auch verantwortlich für die Sehkraftverminderung, die in einer gewissen Zahl von Fällen festgestellt wurde, und ebenso für den abnorm hohen Prozentsatz von Protanopen, der in der Gruppe der Patienten mit Farbsinnstörungen entdeckt wurde.

Es war unmöglich bestimmter Phenothiazinderivate eine stärkere retinotoxische Wirkung zuzuschreiben als andere.

Regelmäßige augenheilkundige Untersuchung von Patienten, die längere Zeit oder/und höhere Dcsen Phenothiazinpräparaten einnehmen ist nach der Meinung des Verfassers notwendig.

\section{SAMENVATTING}

Publikaties betreffende de retinotoxische werking van enkele phenothiazine derivaten waren aanleiding tot het instellen van een oogheelkundig onderzoek bij twee psychiatrische inrichtingen in Nederland.

De pharmacologische werking der phenothiazinen wordt vermeld en een overzicht wordt gegeven van de huidig gebruikte derivaten.

Enkele retinotoxische stoffen worden besproken, waarna een overzicht volgt 
van de literatuur omtrent de oogheelkundige afwijkingen veroorzaakt door phenothiazinen.

561 patienten werden oogheelkundig onderzocht. Hiervan moesten 20 patiënten worden afgevoerd. Van de resterende 541 patienten hadden $343(63.4 \%)$ een retinopathie.

Deze retinopathie bleek sterk significant toe te nemen met de duur van de therapie, significant afhankelijk te zijn van de gemiddelde dagdosis en sterk significant toe te nemen met het stijgen van de totale dosis phenothiazinen.

De retinopathie ging gepaard met een daling van het rustpotentiaal van het oog, aangetoond door middel van elektro-oculografie.

Mogelijk gaf de retinopathie in enkele gevallen aanleiding tot een visusdaling en veroorzaakte het optreden van relatief te veel protans in de groep patiënten met kleurzien stoornissen.

Het was onmogelijk bepaalde phenothiazine derivativen een sterkere retinotoxische werking toe te schrijven dan andere.

Regelmatig oogheelkundig onderzoek van patiënten die gedurende langere tijd en/of in hoge dosis phenothiazine preparaten gebruiken is volgens de auteur geïndiceerd. 


\section{BIBLIOGRAPHY}

ADLER, F. H. Physiology of the Eye. Saint Louis: The C. V. Mosby Company. (1965). ALKEMADE, P. P. H. Fenothiazine retinopathie, Ned. T. Geneesk. 110: 1687 (1966).

Phenothiazine retinopathy, Ophthalmologica, 155: 70-76 (1968).

Annotation, Lancet: 331 (1965 - 2).

APPELBAUM, A. An ophthalmoscopic study of patients under treatment with thioridazine. Arch. Ophthal. (Chicago) 69:578-580 (1963).

ARDEN, G. B. \& A. BARRADA. Analysis of the electro-oculograms of a series of normal subjects. Brit. J. Ophthal. 46: 468-482 (1962).

- - \& J. H. KELSEY. New clinical test of retinal function based upon the standing potential of the eye. Brit. J. Opht/ral. 46: 449-467 (1962).

AYD, F. J. A survey of drug-induced extrapyramidal reactions. J. amer. med. Ass. 175: 1054-1060 (1961).

Chlorpromazine: ten years experience, J. amer. med. Ass. 184: 51-54 (1963). BACON, H. M. Eosinophilia associated with chlorpromazine therapy, Amer. J. Psychiat. 120: 915-916 (1964).

BallantyNe, A. J. \& I. C. MiChaelson. Textbook of the Fundus of the Eye. Edinburgh and London: E. \& S. Livingstone Ltd. (1962).

BAN. T. A. \& H. E. LEHMANN. Skin pigmentation, a rare side effect of chlorpromazine. Canad. Psychiat. Ass. J. 10: 112-124 (1965).

BARSA, J. A. \& J. C. SAUNDERS. A peculiar photosensitivity reaction with chlorpromazine. Psychopharmacologia (Berl.) 7: 138-143 (1965).

J. C. NEWTON \& 3. C. SAUNDERS. Lenticular and comeal opacities during phenothiazine therapy, J. Amer. med. Ass. 193: 98-100 (1965).

BAUMANN, H. Treten nach langdaurender und hochdosierter Largactil Therapie Schädigungen des Sehorgans auf? Klin. Mbl. Augenheilk., 130: 769-793 (1957).

BEEHLER. C. C., N. L. NEWTON, J. F. CULVER \& T. J. TREDICI. Retinal detachment in adult dogs resulting from oxygen toxicity. Arch. Ophthal. (Chicago) 71:665-670 (1964).

- w. ROBERTS \& W. SALEM. Experimental retinal detachments, Arch. Ophthal. (Chicago) 79: 759-762 (1968).

BUERENT, P. La chlorpromazine en ophtalmologie. Presse méd. 62: 1217 (1954).

BOCK, R. \& J. SWAIN. Ophthalmologic findings in patients on long term chlorpromazine therapy. Amer. J. Ophthal. 56: $808-810$ (1963).

Bradley. P. B. Tranquilizers, Phenothiazine Derivatives in Physiological Pharmacology, New York and London: Academic Press (1963).

BÜNAU V., F. Klin. Mbl. Augenheilk. $83: 345$ (1929).

BURIAN, H. M. \& M. C. FLETCHER. Visual functions in patients with retinal pigmentary degeneration following the use of N.P. 207. Arch. Ophthal. (Chicago) 60:612629 (1958).

BUSCH, K. TH., G. BUSCH \& W. LEHMANN. Zur Frage von Netzhautdegeneration nach Anwendung hoher Phenothiazindosen in der Psychiatrie. Klin. Mbl. Augenheilk. 143: 743-749 (1963).

BUTLER, I. Oogafwijkingen ten gevolge van het gebruik van chloroquine en hydroxychloroquine. Academisch proefschrift. Rotterdam: Bronderoffset (1966). 
CAIRNS, R. J., H. S. CAPOORE \& X. D. R. GREGORY. Oculocutaneous changes after years on high doses of chlorpromazine. Lancet: $239-24 l(1965-1)$.

CAMERON, M. E. Ocular melanosis with special reference to chlorpromazine. Brit. J. Ophthal. 51:295-305 (1967).

CASSANO. G. B., S. E. SJÖSTRAND, G. F. PLACIDI \& E. KLANSSON. Eye distribution of [ ${ }^{3 G}$ S] chlorpromazine. $\left[{ }^{14} \mathrm{C}\right]$ amitriptyline. $\left[{ }^{33} \mathrm{~S}\right]$ thiopenthone and $\left[{ }^{14} \mathrm{C}\right]$ phenobarbitone in the cat. Exp. Eye Res. 7: 196-199 (1968).

CERLETTY, A. \& W. MEIER-RUGE. Toxicological studies on phenothiazine induced retinopathy, Proc. Europ. Soc. Study Drug Toxicity. IX: 170-188, Excerpta Med. Int. Congr. Ser. .No. 145 (1967).

CONNELL, M. M., B. J. POLEY \& J. R. MCFARLANE. Chorioretinopathy associated with thioridazine therapy. Arch. Ophthal. (Chicago) 71: $816-821$ (1964).

CONSTANT, M. A. \& B. BECKER. Experimental Tonography. Arch. Ophthal. (Chicago) 56: $19-25(1956)$.

CRAANDLIK. A. Fluorescence angiography in central retinal vein occlusion. Perspectives in ophthalmology. 57-64. Editor $k$. E. Henkes, Excerpta Med. Found. (1968).

- \& A. L. AAN DE KERK. Retinal photography using panchromatic and orthochromatic films. Brit. J. Ophthal. 53:568-573 (1969).

DeEDS. F., A. B. STOCKTON \& J. O. THOMAs. Studies on phenothiazine. J. Pharmacol. exp. Ther. 65: 353-372 (1939).

DELONG, S. L.. B. J. POLEY \& J. R. MCFARLANE. Ocular changes associated with longterm chlorpromazine therapy. Arch. Ophthal. (Chicago) 73: 611-617 (1965).

DENCKER, S. J. \& P. ENOKSON. Ocular changes produced by chlorpromazine. Acta ophthal. (Kbh.) 44: 397-403 (1966).

___ \& P. S. PERsson. Pigment deposits in various organs during phenothiazine treatment. Acta psychiat. scand. 43: 21-31 (1967).

DUKE-ELDER, S. Parsons` Diseases of the Eve. London: J. \& A. Churchill Ltd. (1967).

- System of Ophthalmology. London: Henry Kimpton.

EDLER, K. Ocular changes associated with chlorpromazine therapy. Acta ophthal. (Kbh.) 44: 405-409 (1966).

EKrRLICH, P. \& A. LEPPMANN. Über schmerzstillende Wirkung des Methyleenblau, Disch. med. Wschr. 16: 493-494 (1890).

ENGELHARDT, D. M., N. FREEDMAN, B. S. GLICK. L. D. HANKOFF, D. MANN \& R. MARGOLIS. Prevention of psychiatric hospitalization with use of psychopharmacological agents. J. amer. med. Ass. 173:147-149 (1960).

FINN, R. Pigmentary retinopathy associated with thioridazine: report of a case with a maximum daily dose of $1400 \mathrm{mgm}$. Amer. J. Psychiat. 120: 913-915 (1964).

GOAR, E. L. \& M. C. FLEXCHER. Toxic chorioretinopathy following the use of N.P. 207. Amer. J. Ophthal. 44: 603-608 (1957).

Goodman, L. s. \& A. GILman. The Pharmacological Basis of Therapeutics. New York: Macmillan Company (1967).

GRANT. w. M. Toxicology of the Eye. Springfield - Illinois - U.S.A.: Charles C. Thomas (1962). 
GREINER, A, C. \& K. BERRY. Skin pigmentation and corneal and lens opacities with prolonged chlorpromazine therapy. Canad. med. Ass. J. 90: 663-665 (1964).

- $\&$ G. A. NKCOLSON. Pigment deposition in viscera associated with prolonged chlorpromazine therapy. Canad. med. Ass. J. 91: 627-635 (1964).

—_— \& R. A. BAKER. Therapy of chlorpromazine melanosis, a preliminary report. Canad. med. Ass. J. 91 : 636-638 (1964).

- - New side effects in prolonged chlorpromazine therapy. Canad. Psychiat. Ass. J. 10: 109-111 (1965).

_- _- Schizophrenia melanosis. Lancet: $1165(1965-2)$.

GUNBY, B., K. SANVIG \& O. W. STEENFELDT-FOSS. Late oculocutaneous complications in phenothiazine therapy. Acta psychiat. scand. 42: 97-110 (1966).

HAASE, H. I. \& P. A. J. JANSSEN. The action of neuroleptic drugs. Amsterdam: NorthHolland Publishing Company (1965).

HAGOPIAN, V., D. B. STRATTON \& R. D. BUSTEK. Five cases of pigmentary retinopathy associated with thioridazine administration. Amer.J. Psychiat. 123:97-100(1966).

HARTINETT, B. S. Liver damage and eosinophilia following chlorpromazine therapy. Brit. med. J.: $1458-1459$ (1955-1).

HASHIMOTO, K., W. WIENER, J. ALBBERT \& R. G. NELSON. An electron microscopic study of chlorpromazine pigmentation. J. invest. Derm. 47: 296-306 (1966).

HENKES, H. E. Electro-oculography as a diagnostic aid in phenothiazin retinopathy. Trans. ophthal. Soc. U.K. LXXXVII: 285-287 (1967).

- Oogafwijkingen ten gevolge van geneesmiddelen gebruik. Leiden: Stafleu's wetenschappelijke uitgevers maatschappij N.V. (1968).

- G. H. M., VAN LITH, P. D. GAISNER \& J. R. DE HAAS. Electrodiagnostic procedures in diabetes. ISCERG Symp. Ghent 1966: 393-402, Basel/New York: Karger (1968).

- . J. DENIER VAN DER GON, G. W. VAN MARLE \& H. P. SCHRERNEMACHERS. Electrooculography. Brit. J. Ophthal. 52: 122-126 (1968).

HOBBS, H. E., A. SORSBY \& A. FREEDMAN. Retinopathy following chloroquine therapy. Lancet: $478-480$ (1959-2).

HOFMAN, J. G. Een weinig bekende bijwerking van largactil. Voordrachtenreeks, 9:54 58 (1967).

hogan, M. J. \& L. E. Zmmerman. Ophthalmic Pathology. Philadelphia - London: W. B. Saunders Company (1962).

HOLLISTER, L. Adverse reactions to phenothiazines. J. amer. med. Ass. 189: 311-313 (1964).

- \& J. C. Kosek. Sudden death during treatment with phenothiazine derivatives. J. amer. med. Ass. 192: 1035-1038 (1965).

IPPEN, H. Licht beeinflußte Arzeneimittel - Nebenwirkungen an der Haut. Disch. med. Wschr. 87: 480-488 (1962).

JEss, A. Die Gefahren der Chemotherapie für das Auge, insbesondere über eine das Sehorgan schwer schädigende Komponente des Chinins und seiner Derivate. v. Graefes Arch. Ophthal. 104: 48-74 (1921).

JOHNSON, A. W. \& W. J. BUfFaloE. Chlorpromazine enithelial keratonathy. Arch. Ophthal. (Chicago) 76: 664-667 (1966). 
JUNG, E. G., M. SCHWARZ-SPECK \& G. KORMANY. Beitrag zur Photoallergie auf Chlorphenothiazine. Schweiz. med. Wschr. 93: 249-250 (1963).

KASSMAN, T. \& L. WETTERBERG. Lens opacities and porphobilinogen-like substance in urine associated with levomepromazine. Acta psychiat. scand. 43: 163-168 (1967).

KELSEY, J. H. Variations in the normal electro-oculogram. Brit. J. Ophthal. 51:44-49 (1967).

KrelHolz. P. Zur psychiatrische Pharmakotherapie im Klinik und Praxis. Bern/Stuttgart: Hans Huber (1965).

коCH, R., Schlußbericht über die Tätigkeit der deutschen Expedition zur Erforschung der Schlafkrankheit. Dtsch. med. Wschr. 33: 1889-1895 (1907).

KRILL. A. E., F. W. NEWELL \& M. I. CHISHTT. Fluorescin studies in diseases affecting the retinal pigment epithelium. Amer. J. Ophthal. 66: 470-484 (1968).

LABORM, H., P. KUGUENARD \& R. ALLUAUME. Un nouveau stabilisateur neuro-végétatif. le 4560 RP. Presse méd. 60: 206-208 (1952).

LEA, A. J. J. ment. Sci. 101: 538 (1955).

Leading articles. Chlorpromazine melanosis. Brit. med. J. 630-631 (1967).

LOEHNER, C. A. The therapeutic effect of adrenal cortex extract on the psychotic patient. Endocrinology (Springfield) 23: 507-520 (1938).

LUCAS, D. R., J. P. NEWHOUSE \& J. B. DAVEY. Experimental degeneration of the retina. Brit. J. Ophthal. 41:313-316 (1957).

MANSON-BAHR. P. Phenothiazine as an anthelmentic in threadworm and roundworminfections. Lancet: $808-809$ (19.40).

MARGOLIS, L. H. \& J. L. GOBLE. Lenticular opacities with prolonged phenothiazine therapy. J. amer. med. Ass. 193:95-97 (1965).

MATHALONE, M. в. R. Oculocutaneous effects of chlorpromazine. Lancet: $111-112$ (1965-2).

- Ocular complications of phenothiazines. Trans, ophthal. Soc. U.K. LXXXVI: 77-100 (1966).

—- Eye and skin changes in psychiatric patients treated with chlorpromazine. Brit. J. Ophthal. 51:86-93 (1967).

MAY, R. H., P. SELYMES. R. D. WEEKLEY \& A. M. POTTS. Thioridazine therapy: results and complications. J. nerv. ment. Dis. 130: 230-234 (1960).

MCCLANAHAN, W, S., J. E. HARRIS, W. H. KNOBLOCH, L. M. TREDICI \& R. L. UNDASCO. Chronic phenothiazine derivative administration. Arch. Ophthal. (Chicago) 75: 319-325 (1966).

MCDONALD, C. J., R. S. SNELL \& A. B. LERNER. The effect of chlorpromazine on oculocutaneous pigmentation in the guinea pig. J. invest. Derm. 49: 39-42 (1967).

McisaAC, W. M. A biochemical concept of mental disease. Postgrad. Med. 30: $/ 1 /-118$ (1961).

MEIER-RUGE, W. Die Morphologie der experimentellen Chlorochinretinopathie des Kaninchens. Ophthalmologica, 150: /27-137 (1965).

_- Experimental investigation of the morphogenesis of chloroquine retinopathy. Arch. Ophthal. (Chicago) 73: 540-544 (1965). 
— Medikamentöse Retinopathie. Stuttgart: Georg Thieme Verlag (1967).

\& A. CERLETTI. Lesions of the retina by chloroquine and phenothiazine; a comparative morphological and pathophysiological study, XXth Int. Congr. Ophthal., Excerpta Med. Int. Congr. Ser. No. 114 (1966).

\& - Zur experimentellen Pathologie der Phenothiazin-Retinopathie. Ophthalmologica 151: 512-533 (1966).

- F. KALBERER \& A. CERLEXTX. Mikrohistoautoradiographische Untersuchungen ïber die Verteilung von tritiummarkierten Phenothiazine im Auge. Experientia, 22: $1-7$ (1966).

MORRISON, S. B. Transient visual symptoms associated with Mellaril medication. Amer. J. Psychiat. 116: 1032-1033 (1960).

NICOLSON, G. A., A. C. GREINER, W. J. G. MCFARLANE \& R. A. BAKER. Effect of penicillamine on schizophrenic patients. Lancet: $344-347$ (1966-1).

NOELL, W. K. Electrophysiologic study of the retina during metabolic impairment. Amer. J. Ophthal. 35: 126-133 (1952).

- Experimentally induced toxic effects on structure and function of visual cells and pigment epithelium. Amer. J. Ophrhal. 36: 103-116 (1953).

NoRdManN, J. Personal communication (1969).

NOURI. A. \& J. F. CUENDET. Les atteintes oculaires au cours de traitements prolongés aux neuroleptiques. Schweiz. med. Wschr. 98: 1708-1711 (1968).

OHM, J. Der optokinetische Nystagmus bei Septojodschädigung der Netzhaut. Z. Augenheilk. 83: 338-343 (1934).

PAUL. S. D. \&X. H. LEOPOLD. The effect of chlorpromazine upon the intraocular pressure of experimental animals. Amer. J. Ophthal. 41:318 (1956).

- $\&-$ The effect of chlorpromazine (thorazine) on intraocular pressure in experimental animals. Amer. J. Ophthal. 42: 107-112 (1956).

Perrot \& Boujala. Cas pour diagnostic: un visage mauve. Bull. Soc. franç. Derm. Syph. 69: 631 (1962).

PERRY, T. L., C. F. A. CULLING, K. BERRY \& S. HANSEN. 7-Hydroxychlorpromazine: potential toxic drug metabolite in psychiatric patients. Science, 146: 81-83 (1964).

PILlaT, A. Die senile Pigmentierung der Netzhaut (senile Pigmententartung). v. Graefes Arch. Ophthal. 150: 1-27 (1950).

Potrs, A. M. Retinotoxic and choroidotoxic substances. Invest. Ophthal, 1: 290-303 (1962).

- The concentration of phenothiazines in the eye of experimental animals. Invest. Ophthal. 1: 522-530 (1962).

- Uveal pigment and phenothiazine compounds. Trans. amer. ophthal. Soc. 60 : 517-552 (1962).

- The reaction of uveal pigment in vitro with polycyclic compounds. Invest. Ophthal. 3: $705-416$ (1964).

- Further studies concerning the accumulation of polycyclic compounds on uveal melanin. Invest. Ophthal. 3: 399-404 (1964).

— S. S. WEST \& J. R. SHEARER. Application of television ophthalmoscope to some problems of clinical ophthalmology. Arch. Ophthal. (Chicago) 62:485-499(1959). 
RAB, S. M., M. N. ALAM \& M. D. SADEQUZZAMAN. Optic atrophy during chlorpromazine therapy. Brit. J. Ophthal. 53: 208-209 (1969).

RAMOS. L., J. A. F. CALDEIRA \& A. O. RAMOs. Influence of chlorpromazine intracisternal injection on the intraocular pressure of the rabbit. Ophthalmologica. 153:393399 (1967).

- A. M. GIESBRECHT, J. A. F. CALDEIRA \& A. O. RAMOs. Changes of intraocular pressure and of chloride, sodium and potassium concentrations in aqueous humor and serum of rabbit following chlorpromazine. Ophthalmologica, 157: 279-284 (1969). RIEHM, W., Sitsungbericht. Klin. Mbl. Augenheilk. $78: 87$ (1927).

RINTELEN, F., G. HOTZ \& P. WAGNER. Zur Klinik und experimentellen Pathologie der Pigmentepithelerkrankung nach Medikation met einem Piperidiaphenothiazin. Ophthalmologica, 133: 277-283 (1957).

RIVES. H. \& J. PELlerat. Doses et réactions therapeutiques inhabituelles. Presse méd. 74: 2254 (1966).

ROGGENkÄMPER, w. Akuter Pigmentzerfall der Netzhaut infolge Septojodintoxikation. Klin. Mbl. Augenheilk. 79: 827-828 (1927).

SALLMANN, L. Über Netzhautschädigung durch Salze der unterjodigen, unterbromigen und unterchlorigen Säure. Z. Augenheilk. 80: 342-35l (1933).

SANDVIG, $\mathrm{K}$. Corneal and lens changes after prolonged treatment with chlorpromazine. Acta ophthal. (Kbh.) 43: 730-734 (1965).

SANNA, M. La retrobulbare di largactil nel glaucoma acuto. Atti. Soc. Oftal. Lombarda, 1: 19-23 (1956), quoted from Excerpta Med. (Sect. XII) 1958: 484.

SARIN, L. K., I. H. LEOPOLD \& N. W. WINKELMAN. Ocular examinations in outpatients given long-tern chlorpromazine therapy. J. amer. med. Ass. 198: 789-790 (1966).

SATANOVE. A. Pigmentation due to phenothiazines in high and prolonged dosage. J. amer. med. Ass. 191: 263-268 (1965).

- \& MCINTOSH. Phototoxic reactions induced by high dosis of chlorpromazine and thioridazine. J. amer. med. Ass. 200: 209-2J2 (1967).

SCHEERER, R. Akuter Zerfall des retinalen Pigmentepithels nach intravenöser Injektion von Septojod im Wochenbett. Klin. Mbl. Augenheilk. 76: 524-528 (1926).

scort, A. W. Retinal pigmentation in a patient receiving thioridazine. Arch. Ophthal. (Chicago) 70: 775-778 (1963).

smDall, $x$. R. The ocular toxic findings with prolonged and high dosage chlorpromazine intake. Arch. Ophthal. (Chicago) 74:460-464 (1965).

- Phenothiazines in ophthalmology. Int. Ophthal. Clin., 7, 1 (1967), Boston: Little, Brown \& Company.

SORSBY, A. Experimental pigmentary degeneration of the retina by sodium iodate. Brit. J. Ophthal. 25: 58-62 (1941).

- The nature of experimental degeneration of the retina. Brit. J. Ophthal. 25:6265 (19.41).

- J. P. NEWHOUSE \& D. R. LUCAS. Experimental degeneration of the retina. Brit. $J$. Ophthal. $41: 309-312$ (1957).

- \& A. NAKAJMA. Experimental degeneration of the retina. Brit. J. Ophthal. 42: $558-562$ (1958). 
_ E Experimental degeneration of the retina. Brit. J. Ophthal. 42: 563-57I (1958).

VERREY, F. Dégénérescence pigmentaire de la rétine d’origine médicamenteuse. Ophthalmologica, 131: 296-303 (1956).

voGT, A. Lehrbuch und Atlas der Spaltlampenmikroskopie des lebenden Auges. Berlin: Julius Springer (1931).

WAARDENBURG, P. J. Genetics and Ophthalmology. Assen: Royal van Gorcum, (1963). WAGNER, P. Untersuchungen über die Wirkung von Phenothiazinderivaten auf dem Augenhintergrund des Tieres. Klin. Mbl. Augenheilk. 129: 772-781 (1956).

WEEKLEY, R.D., A. M. POTTS, J. REBOTON \& R. H. MAY. Pigmentary retinopathy in patients receiving high doses of a new phenothiazine. Arch. Ophthal. (Chicago) 64:6576 (1960).

WETTERHOLM, D. H., H. L. SNOW \& F. C. WINTER. A clinical study of pigmentary change in cornea and lens in chronic chlorpromazine therapy. Arch. Ophthal. (Chicago) 74: $55-57$ (1965).

ZELICKSON, A. s. Skin pigmentation and chlorpromazine. J. amer. med. Ass. 194: 670$672(1965)$.

- Skin changes and chlorpromazine (some hazards of long term drug therapy), J. amer. med. Ass. 198: 34I-344 (1966).

- \& H. C. ZELLER. A new and unusual reaction to chlorpromazine. J. amer. med. Ass. 188: 394-396 (1964). 


\section{CURRICULUM VITAE}

Boet, Dirk Johannes. Geboren te Sloten, 17 maart 1920.

Middelbare schoolopleiding: Hervormd Lyceum en Christelijke H.B.S. te Amsterdam. Ingeschreven als student aan de Gemeentelijke Universiteit te Amsterdam in 1939. Arts-examen: 25 april 1951.

Assistentschap interne geneeskunde (Hoofd: Dr. J. A. M. Kamberg), Centraal Militair Hospitaal te Den Haag.

Opleiding tot oogarts, Oogziekenhuis te Rotterdam (Hoofd: Prof. Dr. H. J. Flieringa). Sedert december 1955 gevestigd als oogarts te Den Haag. verbonden aan de Inrichting voor Ooglijders (sedert 1965 waarnemend directeur). 

